ارزيابى و مقايسه روشهاى مختلف تخمين يارامترهاى نفوذ در سيستمهاى مختلف آبيارى جويجهاى و رزيمهاى مختلف جريان ورودى

وحيد رضاوردىنزاد'"، حجت احمدى'، محمد همتى' و حامد ابراهيميانr

(تاريخ دريافت:

جكيده

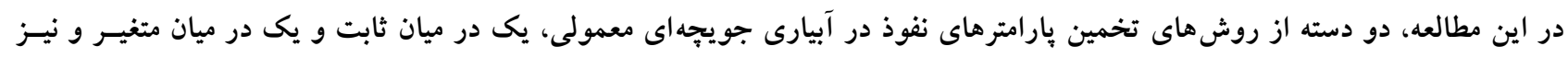

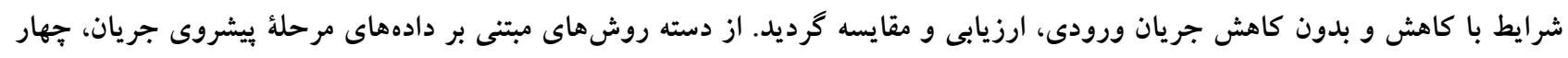

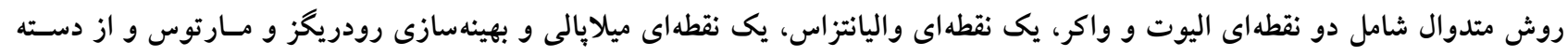

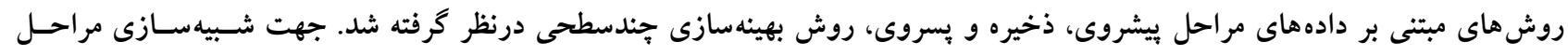

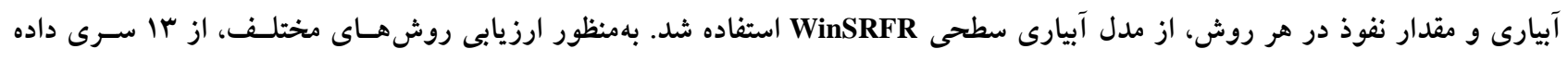

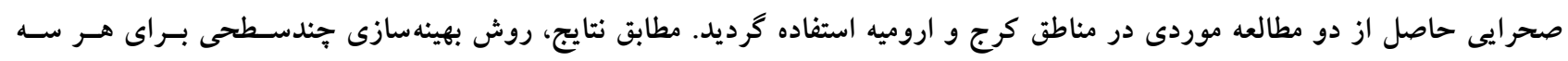

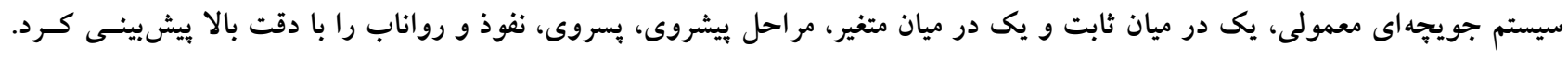

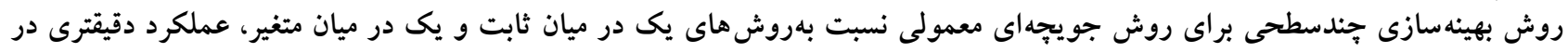

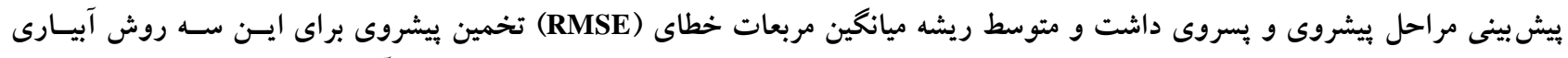

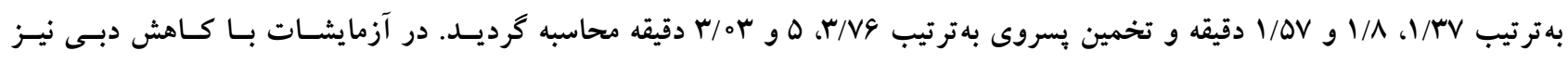

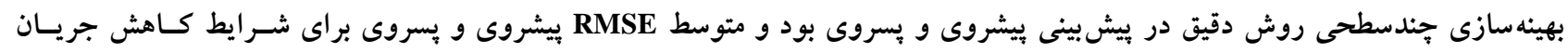

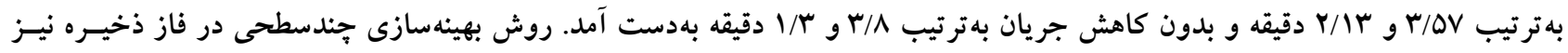

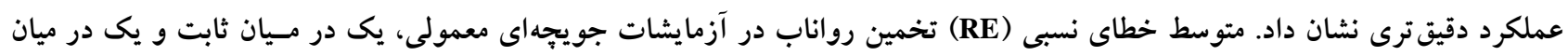

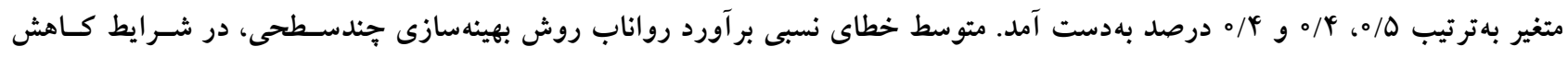

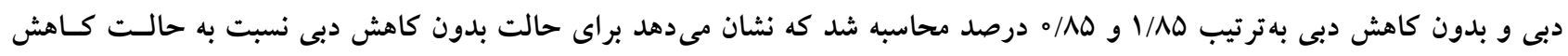

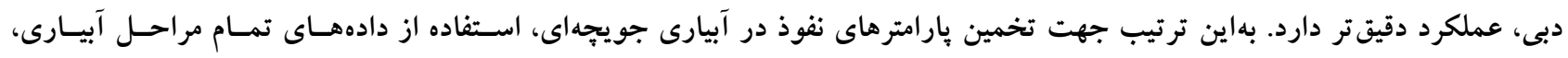

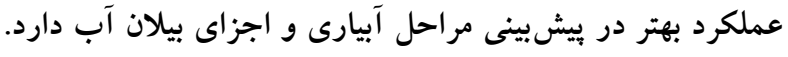

وازههاى كليدى: بيشروى، يسروى، رواناب خروجى، معادله نفوذ، مدل بيلان حجم، مدل WinSRFR

1. كروه مهندسى آب، دانشكده كشاورزى، دانشخاه اروميه

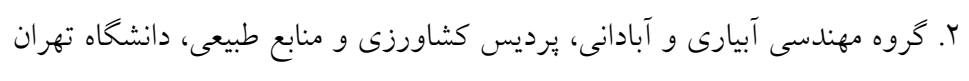

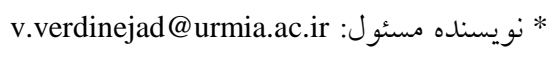


مرحلة بيشروى، ذخيره، تخليه و يسروى (عقبنشينى) مى باشـا

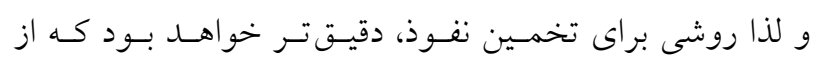

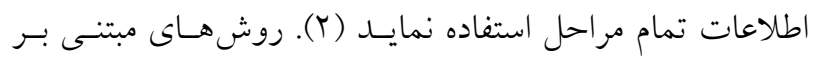

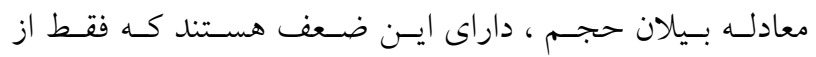
دادههاى مرحله ييشروى استفاده كرده و بخشى از فرايند جريان

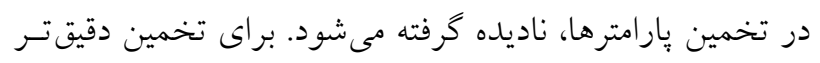

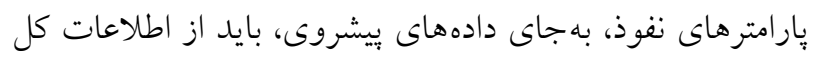

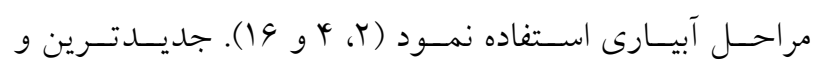
دقيقترين روشهاى تخمين بارامترهاى نفوذ، بر مبنـاى استفاده

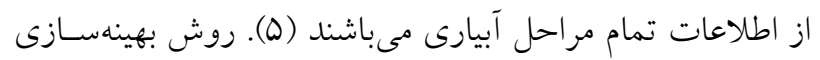
جند سطحى، يكى از جديدترين و دقيقترين روشهاى تخمين

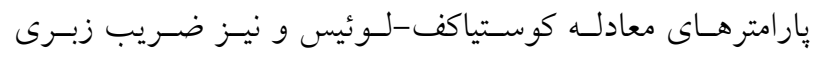
مانينگ مىباشد كه برخلاف روشهاى قبلى، از اطلاعـات تمـام

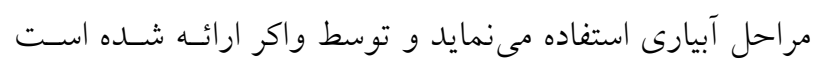

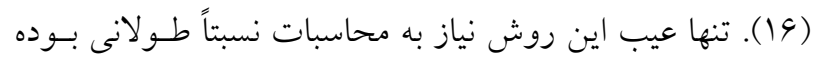

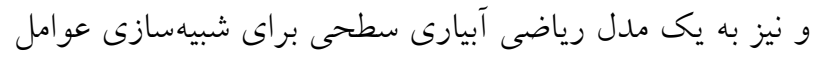

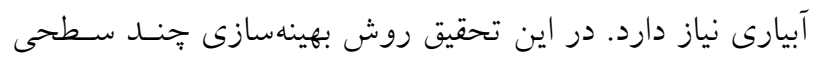

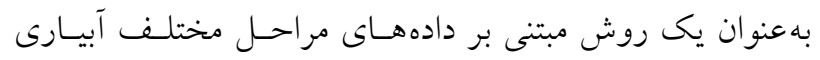

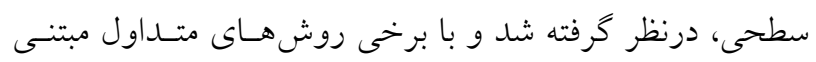

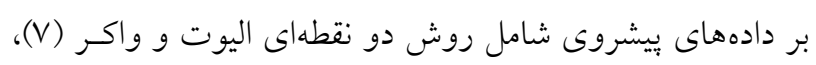

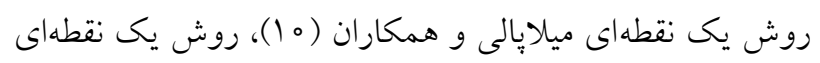

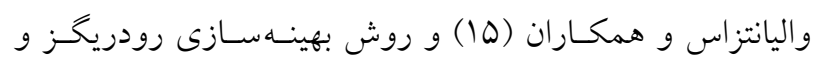

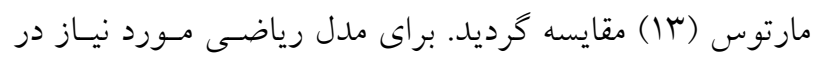

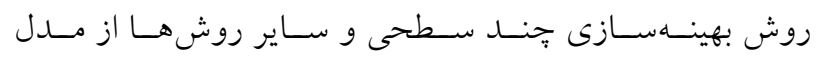

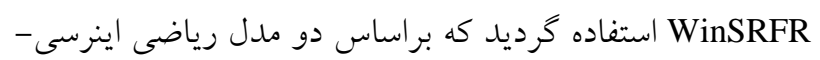

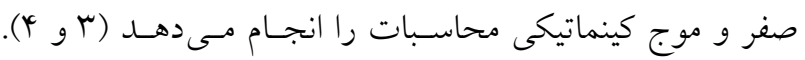
مدل اينرسى- صفر بهسبب سادگى، دقت و دامنه كـاربرد زيـاد،

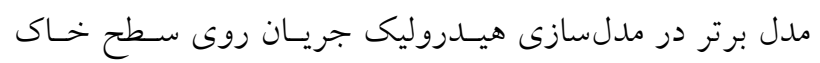

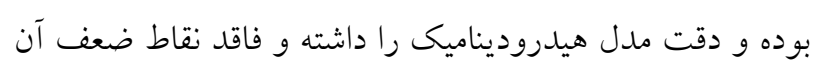

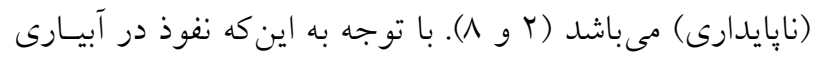

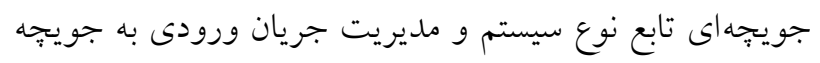

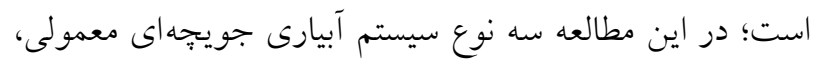

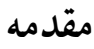

نفوذ آب در خـاك يكسى از عوامـل مهـم در طراحسى و ارزيـابى

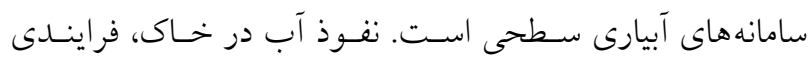

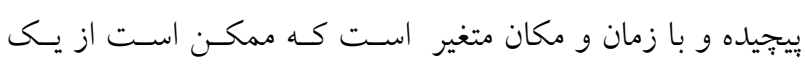

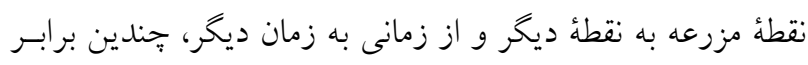

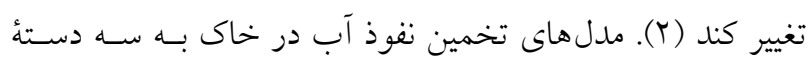

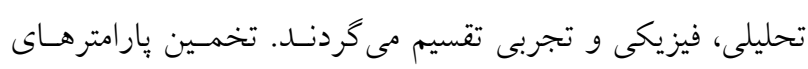

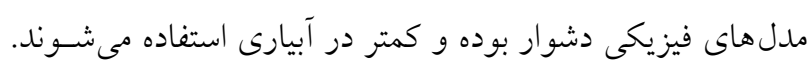

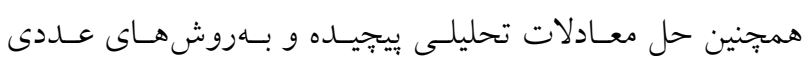

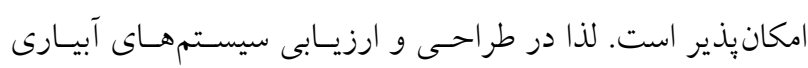

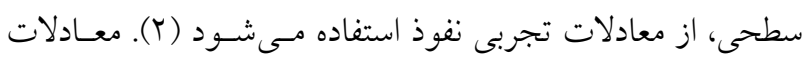

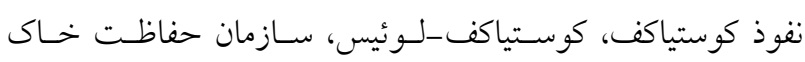

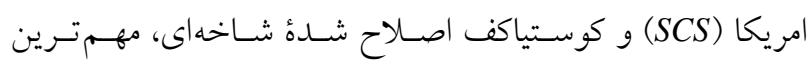
مدلهاى تجربى نفوذ مى باشند. عمدهُ روش هاى تجربسى تخمسين

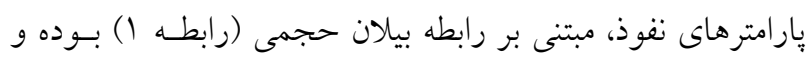

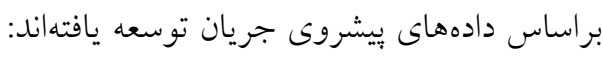
$\mathrm{Qt}=\sigma_{\mathrm{y}} \mathrm{A}_{\mathrm{o}} \mathrm{X}+\int_{\mathrm{s}=\mathrm{o}}^{\mathrm{s}=\mathrm{x}} \mathrm{Z}\left(\mathrm{t}-\mathrm{t}_{\mathrm{s}}\right) \mathrm{ds}$.

كه در آن،

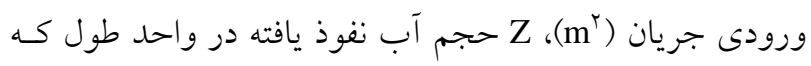

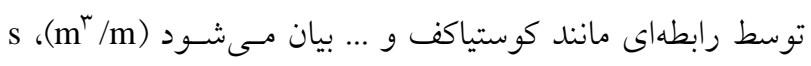

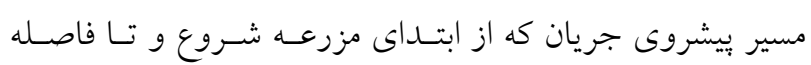

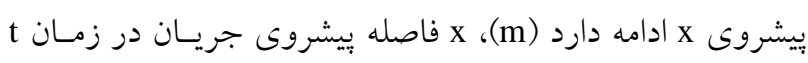

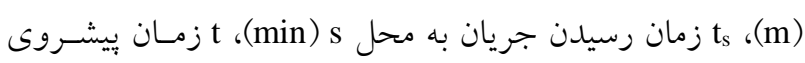

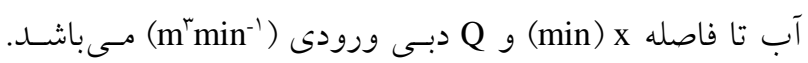

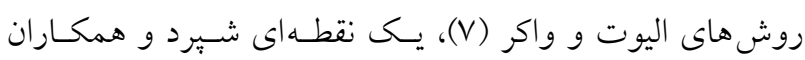

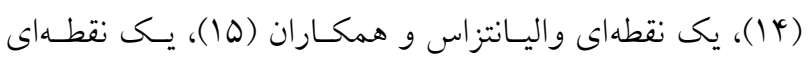
ميلإيالى و همكـاران (م ()، دو نقطـهاى ابراهيميـان و همكــاران

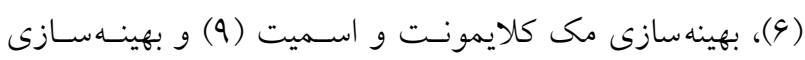

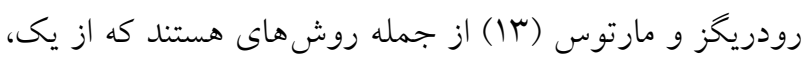

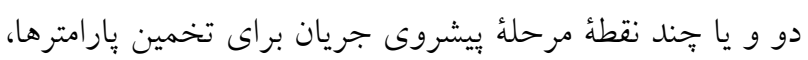

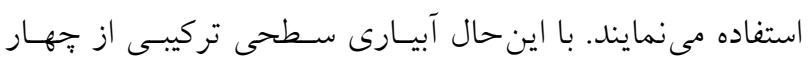


$\mathrm{k}=\frac{\frac{\mathrm{Qt}_{1}}{\mathrm{x}_{1}}-\sigma_{\mathrm{y}} \mathrm{A}_{\circ}-\frac{\mathrm{f}_{\mathrm{o}} \mathrm{t}_{1}}{1+\mathrm{r}}}{\sigma_{\mathrm{z}} \mathrm{t}_{1}^{\mathrm{a}}}$

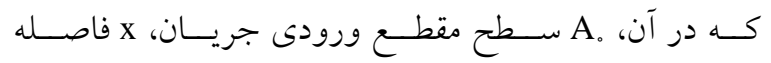

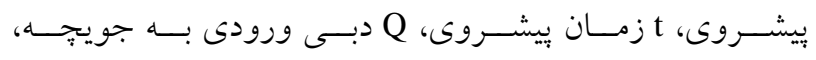

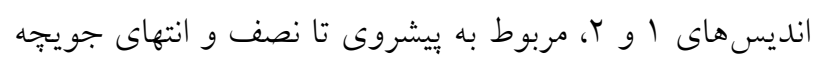

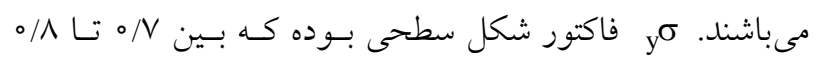

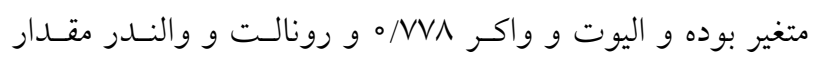

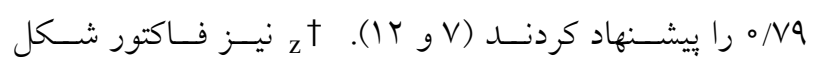
زيرسطحى بوده و از رابطة 9 محاسبه مى گردد (V): $\sigma_{\mathrm{z}}=\frac{\mathrm{a}+\mathrm{r}(1-\mathrm{a})+1}{(1+\mathrm{a})(1+\mathrm{r})}$

در اين روش، فرض بر اين است كه fol قبلاً از ساير روشهها

مانند روش ورودى- خروجى تعيين شده است.

\section{روش يك نقطهاى واليانتزاس و همكاران (10)}

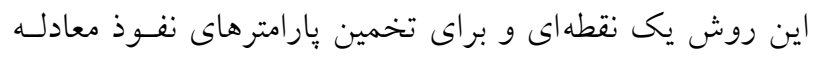
SCS

$$
\mathrm{Z}=\left(k t^{\mathrm{a}}+\mathrm{c}\right) \frac{\mathrm{P}}{\mathrm{w}}
$$

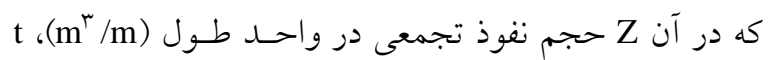

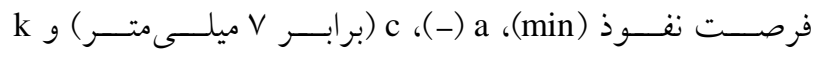

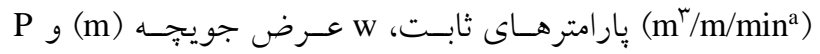
محيط خيس شده (m) بوده كه از رابطة زير محاسبه مى گردد: $\mathrm{P}=0 / 490\left(\frac{9 \circ \mathrm{nQ}}{1000 \sqrt{\mathrm{S}}}\right)^{0 / 4 r \Delta}+0 / 4 r V$

كـهـ در آن Q دبـى ورودى (

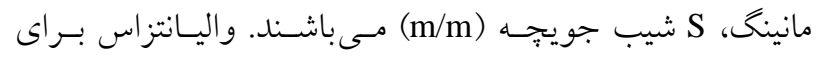

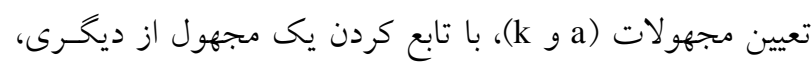

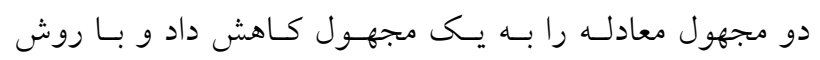

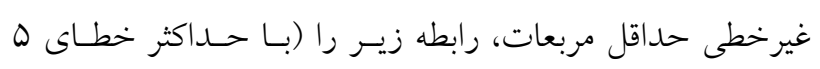
درصد) ارائه كرد (ها (1):
يكى در ميان ثابت و يك در ميان متغير و نيز شر ايط با كـاهش و

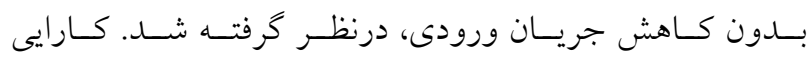
روشهاى مبتنى بر فاز بيشروى با روش مبتنى بر دادههاى تمـام

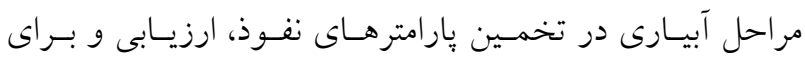

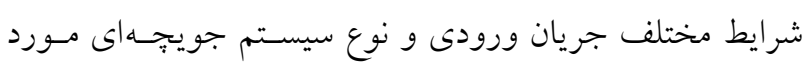
مقايسه قرار كرفت.

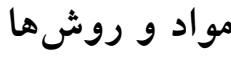
روشهاى دو نقطهاى اليوت و واكر، يكى نقطـهاى واليـانتزاس و

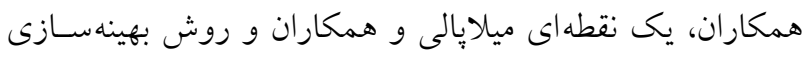

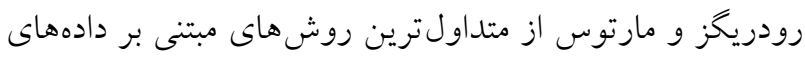

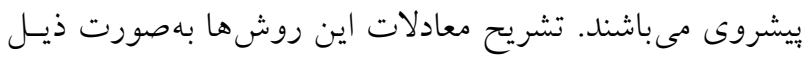

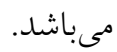

\section{(V) روش دو نقطهاى اليوت و واكر}

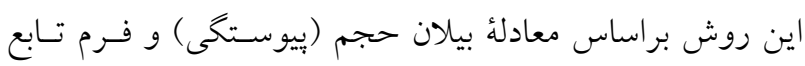

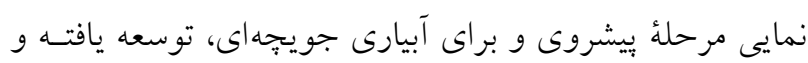

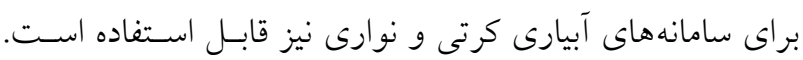

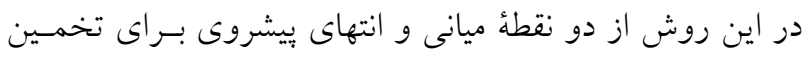
دو يارامتر معادلة كوستياكف- لوئيس (k و a) استفاده مىشود. $\mathrm{Z}=\mathrm{kt}^{\mathrm{a}}+\mathrm{f}_{\mathrm{o}} \mathrm{t}$

fo،(mr/m كه در آن Zجم نفوذ تجمعى در واحد طـول

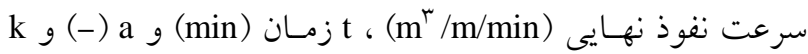

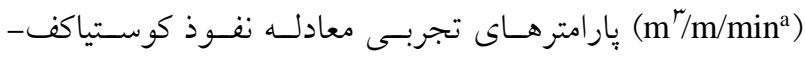
لوئيس مى باشند. با فرض رابطة توانى ييشروى و لكاريتم كرفتن

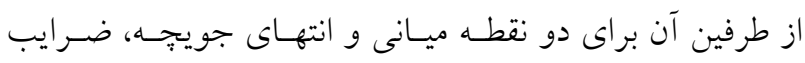

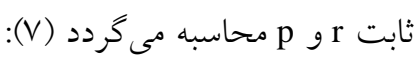
$\mathrm{x}=\mathrm{pt}^{\mathrm{r}}$

$$
a=\frac{\log \left(\frac{Q t_{1}}{x_{1}}-\sigma_{y} A_{o}-\frac{f_{o} t_{1}}{1+r}\right)-\log \left(\frac{Q t_{r}}{x_{r}}-\sigma_{y} A_{\circ}-\frac{f_{0} t_{r}}{1+r}\right)}{\log \left(\frac{t_{1}}{t_{r}}\right)}
$$




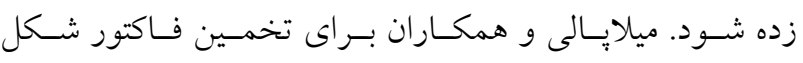

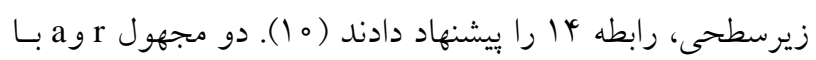

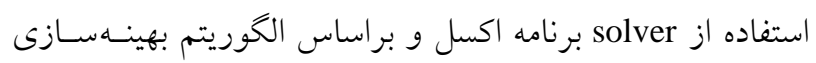

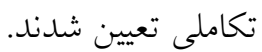

$$
\sigma_{\mathrm{z}}=1-\frac{\operatorname{ar}}{1+\mathrm{r}}+\frac{\operatorname{ar}(\mathrm{a}-1)}{r(r+\mathrm{r})}
$$

\section{روش بهينهسازى رودريخز و مارتوس (r)}

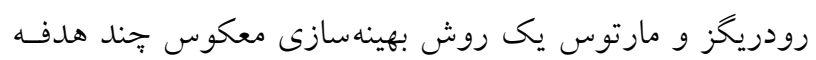

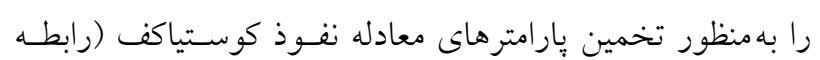

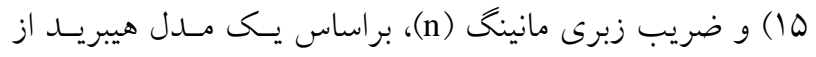

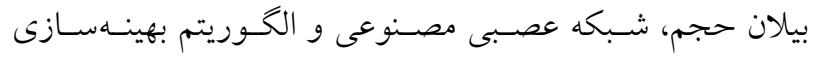
تكامل تفاضلى، توسعه و براى اينمنظور نرمافزار SIPAR-ID

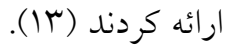
$\mathrm{Z}=\mathrm{kt}^{\mathrm{a}}$ مدل SIPAR-ID براساس دادههاى يبشروى، ضرايب نفوذ و

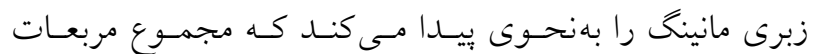

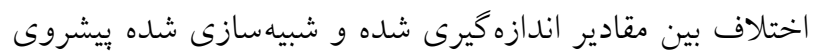
جريان، حداقل شود. توابع هدف درنظر كرفته شده در اين مدل،

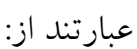
$\mathrm{OF}=$ Min. $\operatorname{SSE}_{\text {Advance Distance }}=\sum_{\mathrm{i}=1}^{\mathrm{N}_{\mathrm{s}}}\left(\mathrm{x}_{\mathrm{i}}-\overline{\mathrm{x}}_{\mathrm{i}}\right)^{r}$ $\mathrm{OF}_{\mathrm{r}}=$ Min. $\mathrm{SSE}_{\text {Flow Depth }}=\sum_{\mathrm{t}=1}^{\mathrm{N}_{\mathrm{t}}}\left(\mathrm{Y}_{\mathrm{t}}-\overline{\mathrm{Y}}_{\mathrm{t}}\right)^{r}$ كـه در آن SSE مجمـوع مربعـات خطــا،

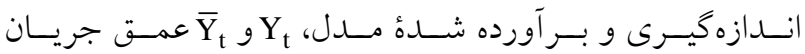

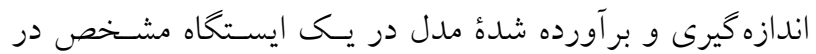
زمانهاى مختلف، NS تعداد ايستخاههاى انــازهذيــى بيشـروى جريان و Nt تعداد اندازهكيرىهاى عمـق جريـان در زمـانهـاى

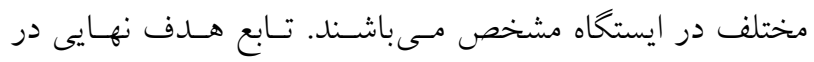
مدل، بهصورت رابطه IV مىباشد: $\mathrm{OF}_{\text {Aggre. }}=\mathrm{w}\left(\mathrm{OF}_{\mathrm{F}}\right)+(1-\mathrm{w})\left(\mathrm{OF}_{\mathrm{r}}\right)$ $\mathrm{k}(\mathrm{a})=\frac{140 \Lambda \wedge \mathrm{a}^{\varphi \Delta}+0 / 1 \uparrow \Lambda(-\ln \mathrm{a})^{-1 / 9 \Delta r}}{1000}$

با جـايكزينى معادلـه نفـوذ SCS در بـيلان حجمسى و حـل

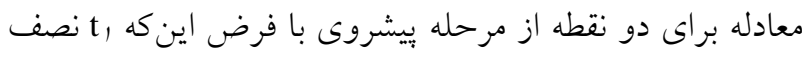

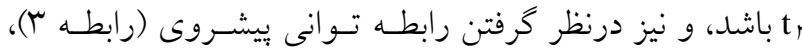
روابط زير را استخراج كردند:

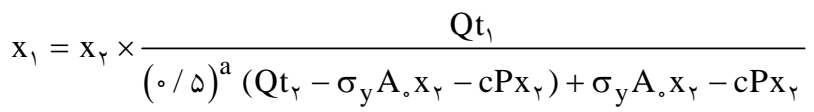

$$
\begin{aligned}
& r=\frac{\log \left(\frac{x_{1}}{x_{r}}\right)}{\log \left(\frac{t_{1}}{t_{r}}\right)}=
\end{aligned}
$$

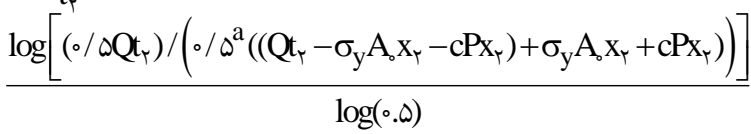

$\sigma_{\mathrm{z}} \mathrm{kt}_{r}^{\mathrm{a}}=\frac{\mathrm{Qt}_{r}-\sigma_{\mathrm{y}} \mathrm{A}_{\mathrm{o}} \mathrm{x}_{r}-\mathrm{cPx}_{r}}{\mathrm{x}_{r} \mathrm{P}}$

تنها مجهول رابطة r ا، aوده كه با يكى الكوريتم بهينهسازى

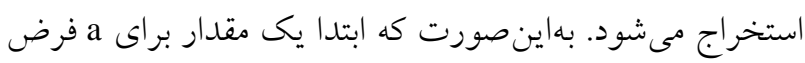

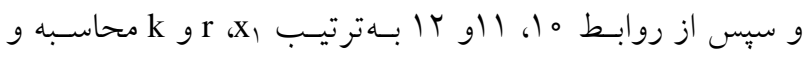

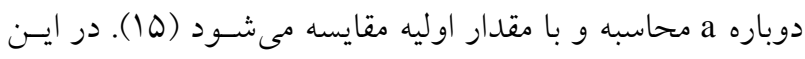
مطالعه، براى محاسبه a از solver برنامه اكسل استفاده كرديد.

\section{روش يك نقطهاى ميلإيالى و همكاران (10)}

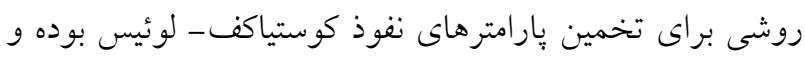

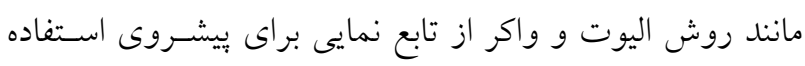

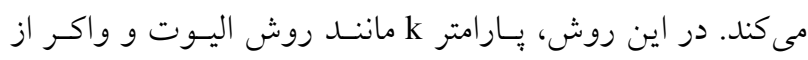

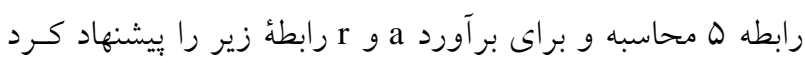
$\left(\frac{f(r, a)=r \log (\circ / \Delta)-\log }{\circ / \Delta a^{a}\left[Q t_{Y}-\sigma_{y} A_{o} X_{Y}-\frac{f_{o} t_{Y} X_{Y}}{1+r}+\sigma_{y} A_{o} x_{Y}+\frac{f_{o}\left(\circ / \Delta t_{Y}\right) x_{Y}}{1+r}\right]}\right)=。$ دو مجهول (agr) با يكى الخوريتم بهينهسـازى بايستى تخمسين 


$$
a^{*}=\min \left[\frac{1}{N} \sqrt{\sum_{i=1}^{N}\left(R_{i}-\bar{R}_{i}\right)^{r}}\right]_{k^{*}, f_{0}{ }^{*}, n}
$$

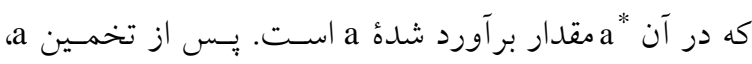

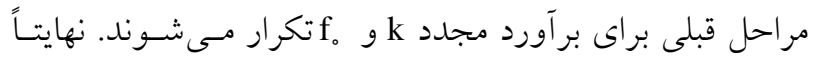

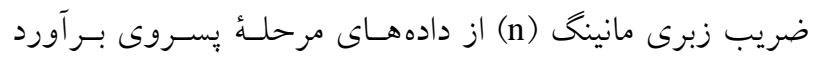

$\mathrm{n}^{*}=\min \left[\left|\mathrm{t}_{\mathrm{R}}-\overline{\mathrm{t}}_{\mathrm{R}}\right|\right]_{\mathrm{a}^{*}, \mathrm{f}_{\mathrm{o}}{ }^{*}, \mathrm{k}^{*}}$

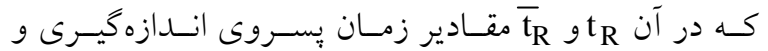
شبيهسازى شده مىباشند. پِس از تخمين n، كليـــ مراحـل قبلى

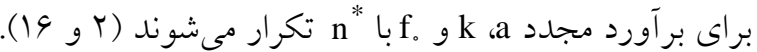

\section{دادههاى مورد استفاده}

براى ارزيابى عملكرد روشهـا، از اطلاعـات سـرى آزمايشـات

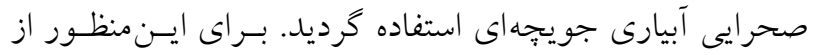
دادههاى دو مطالعه موردى استفاده گرديد كـه در ادامـه تشـريح مى گردد. مطالعه مـوردى اول مربـوط بـهـ تحقيـق ابراهيميـان و همكاران بوده كه در مزرعه يزوهشى يرديس كشاورزى و منـابع

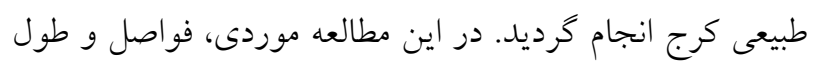

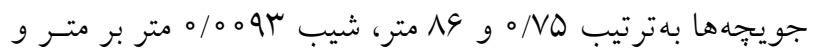
تحت كشت ذرت علوفهاى و با بافـت خهاك لـوم رسى انسى انجـام

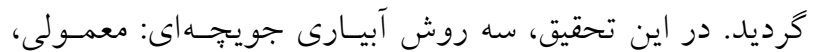
يك در ميان ثابت و يك در ميـان متغيـر، تحــت آزمـايش قـرار كرفـتـ 9 سـرى آزمـايش بـهـهـورت سيستم انتهـا بـاز بـود. مشخصات دادههـاى صـحر ايى مـورد استفاده در ايـن مطالعـه

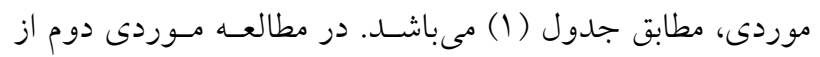

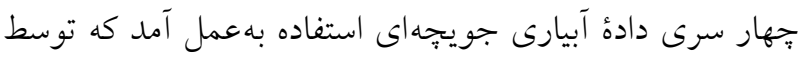

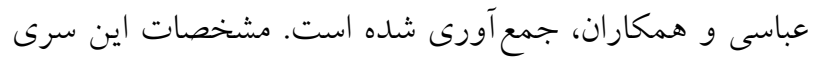

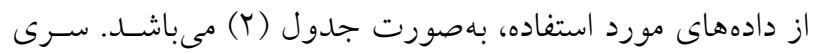

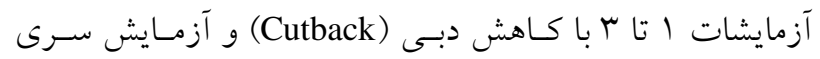

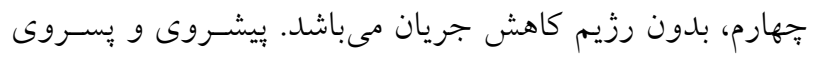

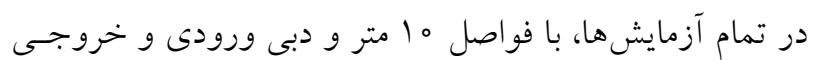

كه در آن W يارامتر وزن مي باشـد. مـــSIPAR-ID عـلاوه براى دادههاى جريان ورودى و يِيشروى، نيازمند هندسه مقطع و

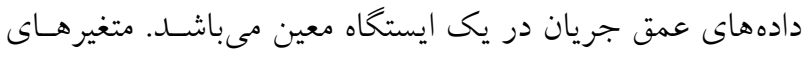
تصميم مدل بهينه سازى شامل ضر ايب معادله نفوذ كوستياكف و

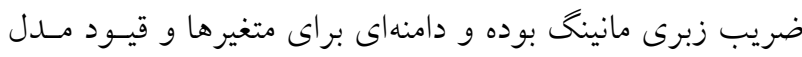

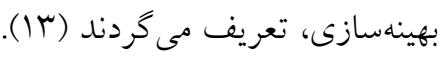

\section{روش بهينهسازى جند سطحى}

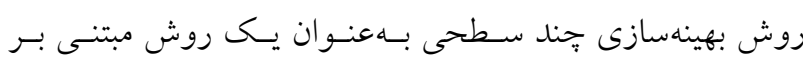

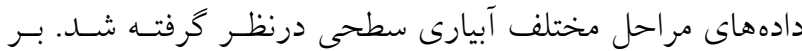

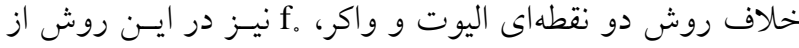

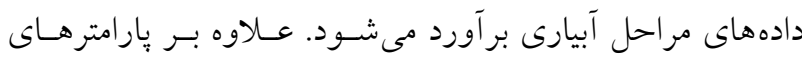

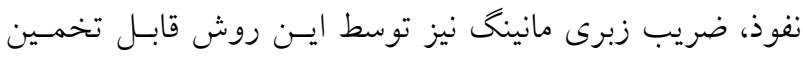

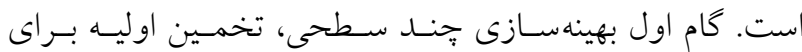

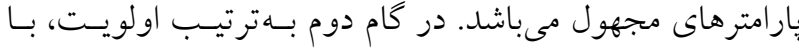

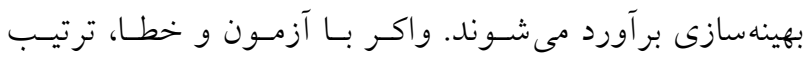

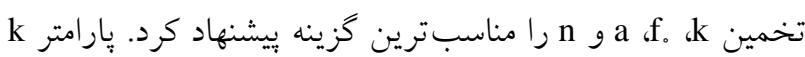

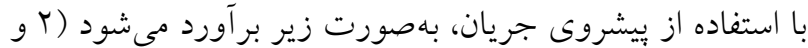

$\mathrm{k}^{*}=\min \left[\left|\mathrm{t}_{\mathrm{L}}-\overline{\mathrm{t}}_{\mathrm{L}}\right|\right]_{\mathrm{a}, \mathrm{f}_{\mathrm{o}} \mathrm{n}}$ كه در آن ${ }^{*}$ مقدار برآورد شده k، و شبيه سازى شده زمان ييشروى بهازاى مقادير تخمين اوليـه

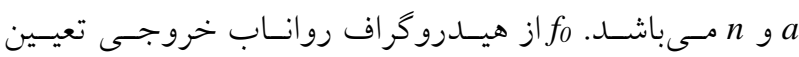
$\mathrm{f}^{*}=\min \left[\frac{1}{\mathrm{~N}} \sqrt{\sum_{\mathrm{i}=1}^{\mathrm{N}}\left(\mathrm{R}_{\mathrm{i}}-\overline{\mathrm{R}}_{\mathrm{i}}\right)^{\mathrm{r}}}\right]_{\mathrm{a}, \mathrm{k}^{*}, \mathrm{n}}$

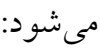

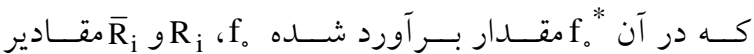
اندازهيرى و شبيهسازى شده دبى رواناب در زمانهاى مختلف

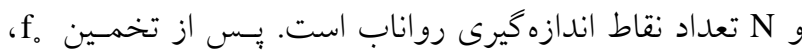

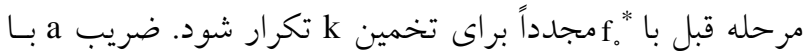

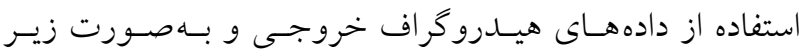
برآورد مىشود: 
جدول ا. مشخصات دادههاى صحرايى مورد استفاده براى 9 سرى آزمايش مطالعه موردى اول

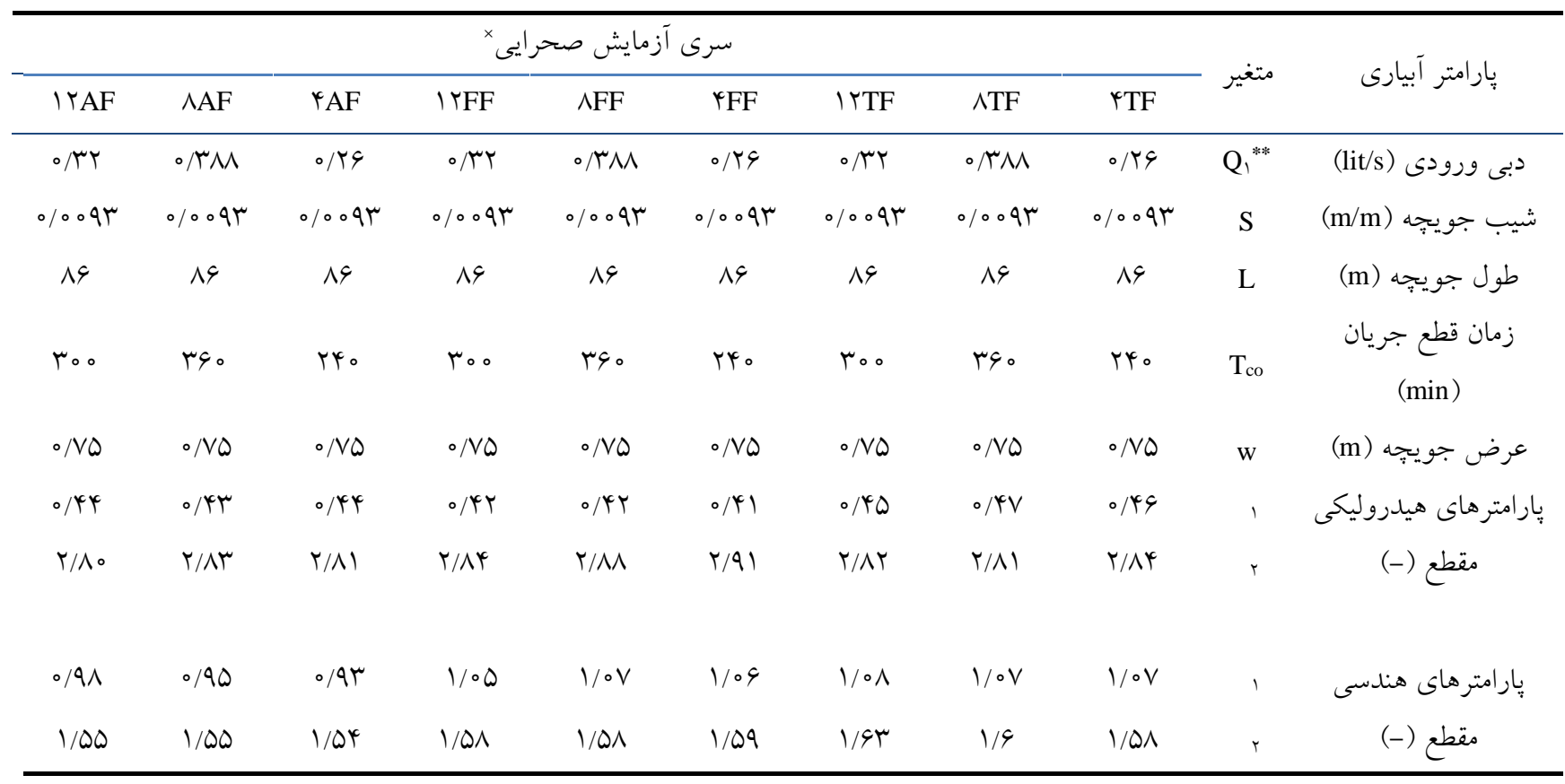

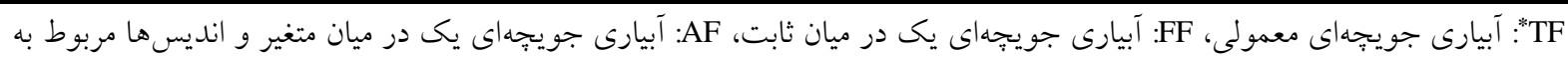
نوبت آبيارى مىباشند "** مبى ورودى بهصورت هيدروگراف بوده و ارقام اين جدول متوسط وزنى دبى ورودى مىباشند

جدولr. مشخصات دادههاى صحرايى مورد استفاده براى جهار سرى آزمايش مطالعه موردى دوم

\begin{tabular}{|c|c|c|c|c|c|}
\hline \multicolumn{4}{|c|}{ سرى آزمايش صحرايى } & \multirow{2}{*}{ متغير } & \multirow{2}{*}{ پֶارامتر آبيارى } \\
\hline سرى † & سرى r & سرى r & سرى 1 & & \\
\hline $1 / \pi \circ 9$ & $1 / 14$ & $1 / T 1$ & $0 / 911$ & $\mathrm{Q}^{* * *}$ & دبى ورودى (lit/s) \\
\hline Iro & $\wedge \vee$ & $\Delta V$ & rt & $r^{T}$ & زمان كاهش دبى (min) \\
\hline- & $0 / 94 V$ & $\circ / N r^{4}$ & $0 / 9 \pi r$ & $\mathrm{Qr}^{* *}$ & دبى كاهش يافته (lit/s) \\
\hline.$/ 01 V Q$ & $0 / 01 V^{e}$ &.$/ 01 \mathrm{VI}$ &.$/ 01 V r$ & S & شيب جويجه (m/m) \\
\hline roo & roo & roo & roo & $\mathrm{L}$ & طول جويجه (m) \\
\hline rro & rro & ko & ko & $\mathrm{T}_{\mathrm{co}}$ & زمان قطع جريان (min) \\
\hline$\circ / N Q$ & $\circ / N Q$ & $\circ / N \Delta$ & $\circ / V Q$ & w & عرض جويجهه (m) \\
\hline OAYT & $0 / 4 q$ & $\circ / \mu \wedge$ & $\circ / T \Delta V$ &, $\mathrm{P}$ & بِارامترهاى هيدروليكى \\
\hline$r / v q$ & $r / V q$ & r/vA & $r / V V$ & ${ }_{\curlyvee} \mathrm{P}$ & مقطع (-) \\
\hline $0 / r q$ & $0 / \mu \wedge$ & $0 / 4 \circ$ & 0 & $\sigma_{1}$ & يارامترهاى هندسى \\
\hline $0 / 90$ & .09 & $\circ / 09$ & $\circ / \Delta \wedge$ & $\sigma_{r}$ & مقطع (-) \\
\hline
\end{tabular}




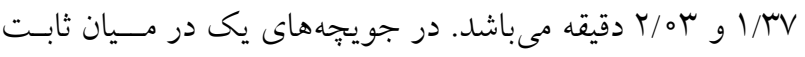

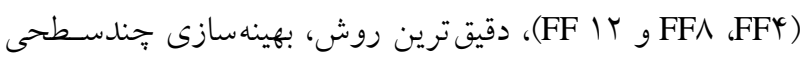

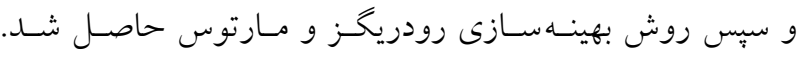

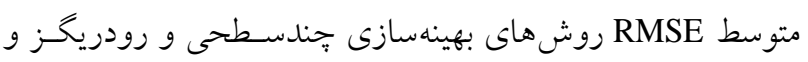

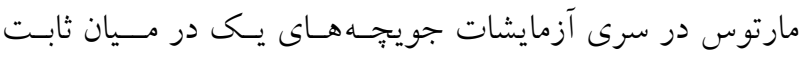

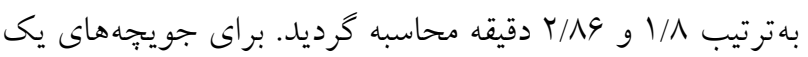

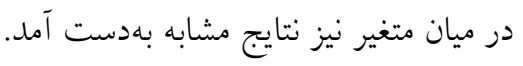

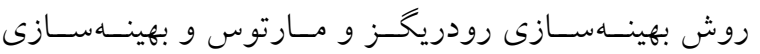
جندسطحى در جويجههاى يك در ميان متغير، دقيقتسرين روش بـوده و متوسط RMSE تخمسين ييشـروى در ايسن جويجهـهــا

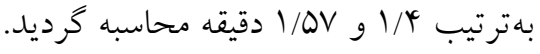

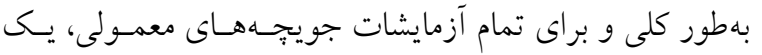

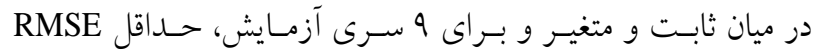

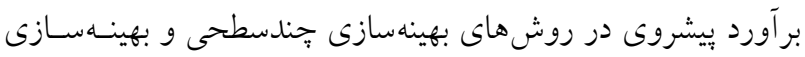

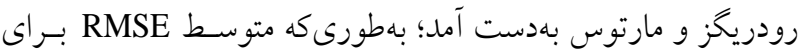

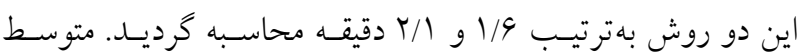

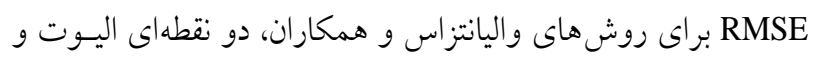

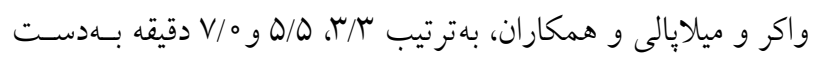

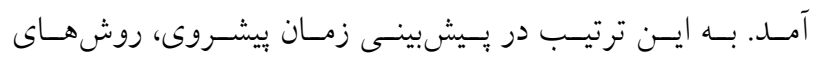

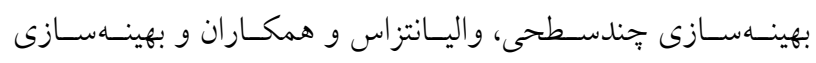

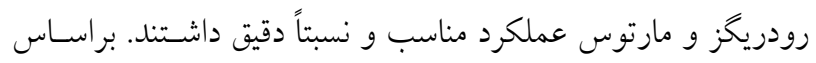

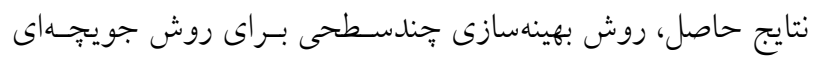

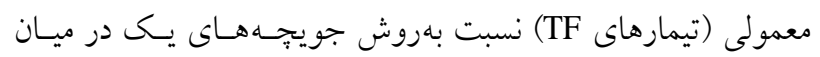

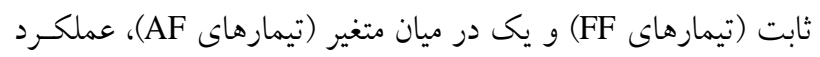

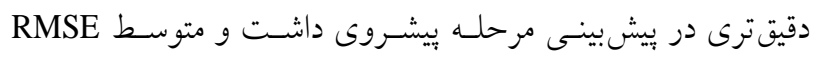

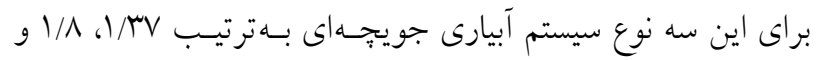
1/OVV

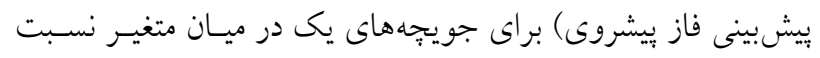
به يك در ميان ثابت، دقيقتر مىباشد.

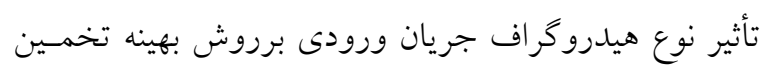
بارامترهاى نفوذ، مطابق جدول ب مىباشد. در سـرى آزمايشـات

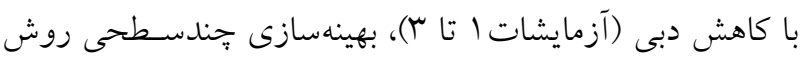

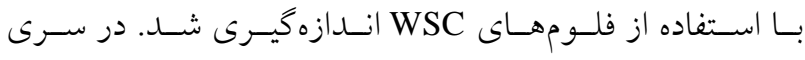

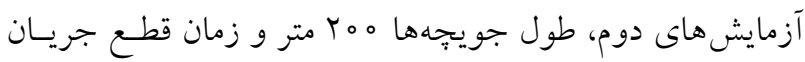

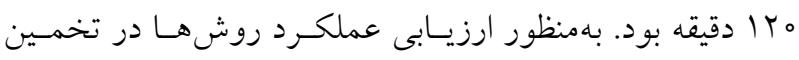

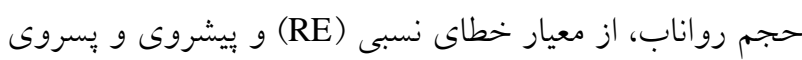
از شاخص ريشه ميانخين مربعات خطا (RMSE) استفاده شد. $\mathrm{RE}=\frac{\left|\mathrm{V}_{\mathrm{p}}-\mathrm{V}_{\mathrm{m}}\right|}{\mathrm{V}_{\mathrm{m}}} \times 10$

RMSE $=\sqrt{\frac{\sum_{\mathrm{i}=1}^{\mathrm{N}}\left(\mathrm{T}_{\mathrm{mi}}-\mathrm{T}_{\mathrm{pi}}\right)^{r}}{\mathrm{~N}}}$

كه در آن، نفوذ يا رواناب اندازه كيرى شده،

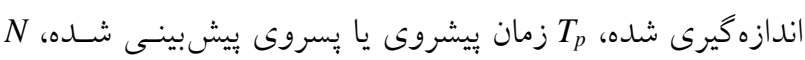

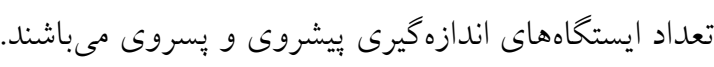

\section{نتايج و بحث}

ييشروى و بسروى

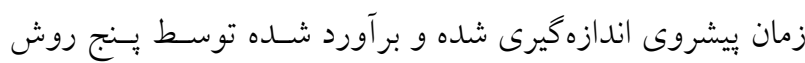

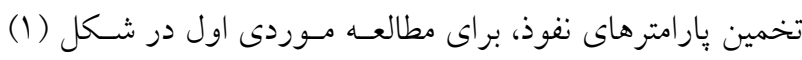

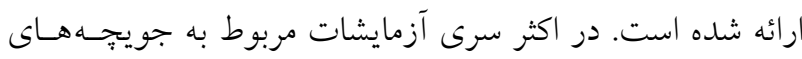

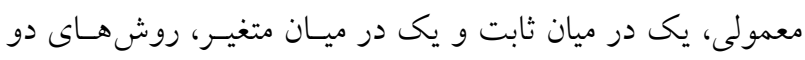

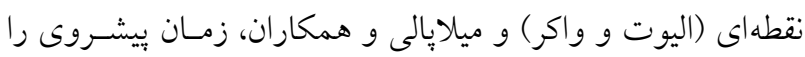

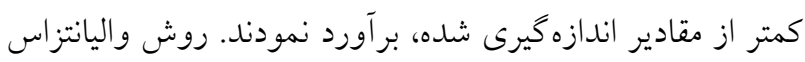

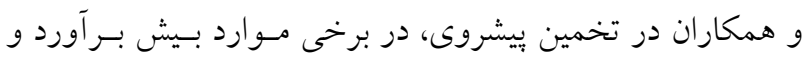

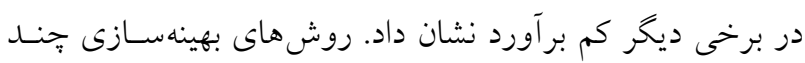

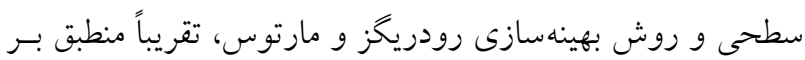
مقادير اندازهكيرى شدة بيشروى بوده و عملكرد بهترى نسبت بــهـ

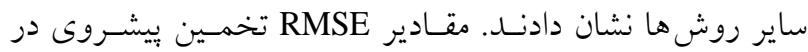

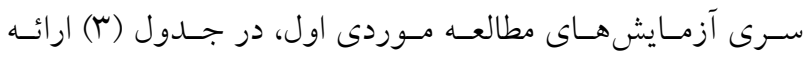

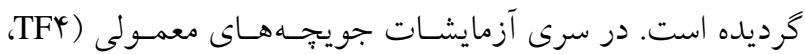
Tو وTF/ بهروش بهينه سازى جندسطحى سبس روش بهينهسازى رودريخـز

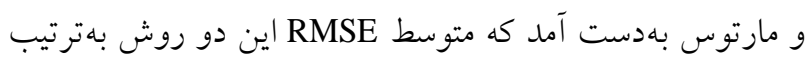



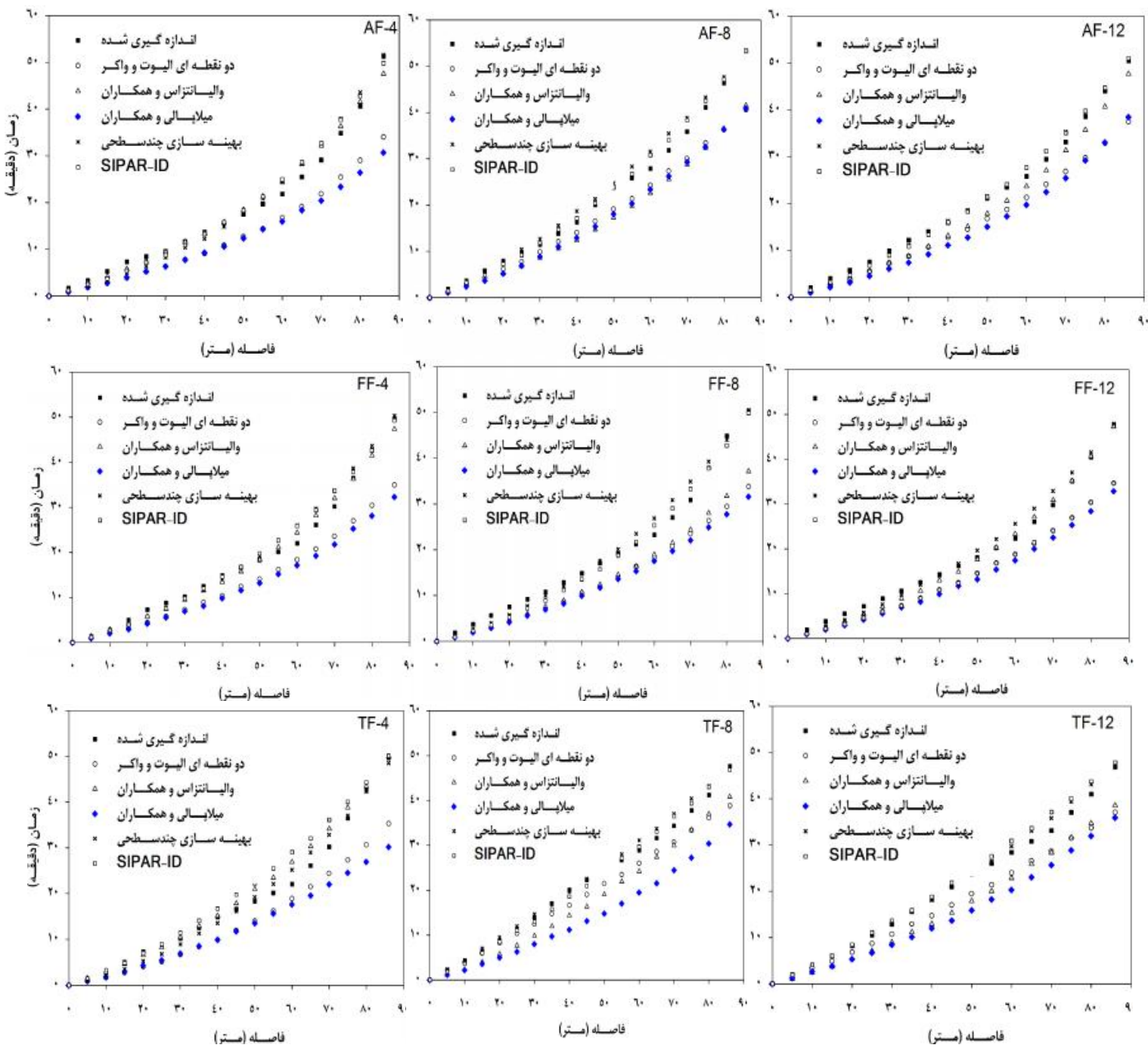

شكل ا. مقايسه مرحله بيشروى اندازهيرى و شبيهسازى شده توسط مدل WinSRFR با روشهاى مختلف براى مطالعه موردى اول

جدولr. مقادير ريشه ميانگين مربعات خطاى (RMSE) برآورد زمان بيشروى در ه سرى آزمايش مطالعه موردى اول (برحسب دقيقه) سرى آزمايش صحرايى

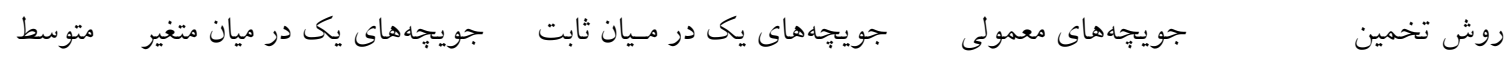

\begin{tabular}{|c|c|c|c|c|c|c|c|c|c|c|}
\hline & $1 T \mathrm{AF}$ & $\wedge \mathrm{AF}$ & rAF & 1 KFF & $\wedge F F$ & ${ }^{\varphi} \mathrm{FF}$ & $1 \Upsilon T \mathrm{TF}$ & $\wedge \mathrm{TF}$ & ${ }^{*} \mathrm{TF}$ & \\
\hline$\Delta / \Delta$ & $0 / 9$ & $0 / 1$ & 9/9 & $\Delta / r$ & $V / r$ & $9 / 0$ & $r / \pi$ & $r / 4$ & 910 & دو نقطهاى اليوت و و اكر \\
\hline$r / \mu$ & $r / Q$ & $\Delta / V$ & $1 / V$ & $1 / r$ & $9 / 1$ & $1 / \pi$ & $\psi / \Lambda$ & $r / r$ & $T / Y$ & واليانتزاس و همكاران \\
\hline $\mathrm{V} / 0$ & $4 \pi$ & $0 / 9$ & $V / V$ & $9 / \pi$ & $N / 1$ & $V / T$ & $4 / 4^{\circ}$ & $N / 1$ & $V / 9$ & ميلإيالى و همكاران \\
\hline 1/9 & $1 / 0$ & $1 / 1$ & $1 / 9$ & $1 / N$ & $1 / 9$ & $1 / \Lambda$ & $1 / T$ & $1 / \pi$ & 1/9 & بهينهسازى تجندسطحى \\
\hline$r / 1$ & $1 / 1$ & $1 / T$ & $1 / 9$ & $\Delta / r$ & $1 / 9$ & $1 / N$ & $1 / N$ & $1 / 1$ & $r / \mu$ & بهينهسازى رودريخز و مارتوس \\
\hline
\end{tabular}


جدول f. مقادير ريشه ميانخين مربعات خطاى بر آورد زمان بيشروى براى جهار سرى آزمايش مطالعه موردى دوم (برحسب دقيقه)

\begin{tabular}{|c|c|c|c|c|c|}
\hline \multirow{2}{*}{ متوسط } & \multicolumn{4}{|c|}{ سرى آزمايش صحرايى } & \multirow{2}{*}{ روش برآورد } \\
\hline & سرى | & سرى r & سرى r & سرى 1 & \\
\hline $4 / 1$ & $1 \% / 4$ & $\Lambda / \circ$ & $r / r$ & $\circ / \Lambda$ & دو نقطهاى اليوت و واكر \\
\hline$\Lambda / \Delta$ & $14 / 9$ & $11 / 4$ & $9 / \mathrm{V}$ & $1 / 1$ & و اليانتزاس و همكاران \\
\hline$r / \mathrm{N}$ & $ه / \Delta$ & $\varphi / \Lambda$ & $r / 1$ & $1 / 0$ & ميلإِالى و همكاران \\
\hline$r / 9$ & $r / \Lambda$ & $9 / 1$ & $T / \Delta$ & $1 / 4$ & بهينهسازى جندسطحى \\
\hline$\Delta / r$ & $9 / 0$ & $\Lambda / 0$ & $r / 1$ & $1 / 4$ & بهينهسازى رودريخز و مارتوس \\
\hline
\end{tabular}

جدوله. ريشه ميانگين مربعات خطاى (RMSE) بر آورد زمان يسروى براى سرى آزمايشات مطالعه موردى اول (برحسب دقيقه)

\begin{tabular}{|c|c|c|c|c|c|c|c|c|c|c|}
\hline \multirow{4}{*}{ 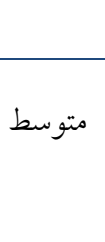 } & \multicolumn{9}{|c|}{ سرى آزمايش صحرايى } & \multirow{4}{*}{ روش تخمين } \\
\hline & \multirow{2}{*}{\multicolumn{3}{|c|}{ جويتههاى يك در ميان }} & \multirow{2}{*}{\multicolumn{3}{|c|}{ جويجههاى يك در ميان }} & \multirow{2}{*}{\multicolumn{3}{|c|}{ جويجههاى معمولى }} & \\
\hline & & & & & & & & & & \\
\hline & $A F \backslash Y$ & $\mathrm{AF} \wedge$ & $\mathrm{AF}{ }^{4}$ & FFIY & FF^ & $\mathrm{FF})^{c}$ & TFIY & TFA & $\mathrm{TFY}^{\mathrm{C}}$ & \\
\hline$y / \circ$ & $r / 。$ & $1 / r$ & $\varphi / V$ & $4 / 9$ & $\Delta / \mu$ & $\Delta / \Gamma$ & $0 / \circ$ & $\Delta / V$ & $1 / 0$ & دو نقطهاى اليوت و واكر \\
\hline$r / \Lambda$ & $r / 4$ & $1 / 0$ & $r / 9$ & $\varphi / \mu$ & $Q / \circ$ & $Y / V$ & $0 / 9$ & $9 / 1$ & $\circ / \wedge$ & واليانتزاس و همكاران \\
\hline $4 / 1$ & $r / 1$ & $1 / r$ & $4 / 9$ & $4 / 9$ & $\Delta / \mu$ & $\Delta / \Gamma$ & $\Delta / \mu$ & $9 / \pi$ & $\circ / 9$ & ميلإِالى و همكاران \\
\hline$r / 9$ & $r / 1$ & $1 / r$ & $\varphi / \Lambda$ & $4 / 9$ & $\Delta / r$ & $4 / 9$ & $4 / 9$ & $9 / 0$ & $\circ / \mathrm{V}$ & بهينهسازى جندسطحى \\
\hline $4 / 1$ & $r / 1$ & $1 / r$ & $\varphi / V$ & $4 / 9$ & $\Delta / \uparrow^{\leftarrow}$ & $\Delta / \Gamma$ & $0 / 1$ & $0 / 9$ & $\circ / 9$ & بهينهسازى رودريخز و مارتوس \\
\hline
\end{tabular}

جدولو. ريشه ميانخين مربعات خطاى بر آورد زمان بِروى براى سرى آزمايشات مطالعه موردى دوم (برحسب دقيقه)

\begin{tabular}{|c|c|c|c|c|c|}
\hline \multirow{2}{*}{ 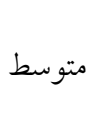 } & \multicolumn{4}{|c|}{ سرى آزمايش صحرايى } & \multirow{2}{*}{ روش بر آورد } \\
\hline & سرى | & سرى ب & سرى ب & سرى 1 & \\
\hline$r / l$ & $1 / \mu$ & $1 / 0$ & $r / 。$ & $T / \mathcal{C}$ & دو نقطهاى اليوت و واكر \\
\hline$T / \mathcal{C}$ & $1 / \wedge$ & $r / Q$ & $r / q$ & $T / \mathcal{A}$ & و اليانتزاس و همكاران \\
\hline$r / 9$ & r/^ & $1 / V$ & $\varphi / r$ & $1 / \wedge$ & ميلإِالى و همكاران \\
\hline $9 / 1$ & $1 / \Gamma$ & $T / r$ & $1 / 0$ & $r / 9$ & بهينهسازى جندسطحى \\
\hline$r / \Lambda$ & $T / \mu$ & $1 / 0$ & $4 / 9$ & $\mu / \mu$ & بهينهسازى رودريكز و مارتوس \\
\hline
\end{tabular}

حاصل شد. مطابق نتايج در هر دو حالت كاهش جريان و بدون كاهش جريان، بهينهسازى جندسطحى دقيقترين روش مىباشد. در بيشبينى بـروى در مطالعه موردى اول مطـابق نتـايج جـدول هه
دقيق در بيشبينى بيشروى بـوده و متوسـط RMSE ايسن روش براى سرى آزمايشات با كاهش جريان برابر r/OV دقيقه و بـراى بلدون كاهش جريان (آزمـايش سـرى جهـارم) برابـر م/ب دقيقــ 
جدولV. نتايج اندازهيرى و ييشينى اجزاى بيلان و خطاى نسبى روشهاى مختلف تخمين بارامترهاى نفوذ براى سرى آزمايشات مطالعه موردى اول

\begin{tabular}{|c|c|c|c|c|c|c|c|c|c|c|}
\hline \multicolumn{9}{|c|}{ سرى آزمايش } & \multirow{2}{*}{ پِارامتر ارزيابى } & \multirow{2}{*}{ 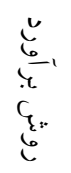 } \\
\hline IrAF & ITFF & IrTF & $\wedge \mathrm{AF}$ & $\wedge \mathrm{FF}$ & $\wedge \mathrm{TF}$ & rAF & ${ }^{\uparrow} \mathrm{FF}$ & ${ }^{4} \mathrm{TF}$ & & \\
\hline$\Delta / \Lambda r$ & $\Delta / \Lambda r$ & $\Delta / \Lambda r$ & 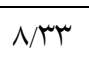 & $N / \Psi^{4}$ & $1 / r^{4}$ & $r / v q$ & r/vV & r/vG & جريان ورودى (m & \\
\hline $1 / 09$ & $1 / N^{4}$ & $r / 19$ & $r / r V$ & $r / \mu V$ & $Y / V q$ & $\circ / \mathrm{AV}$ & $1 / 04$ & $1 / T r$ & رواناب اندازهيرى شده (mr) & $0^{\prime \prime}$ \\
\hline$r V / r$ & $r q / \Lambda$ & $\Delta \psi / V$ & $r q / r$ & $|4| / r$ & $\Delta V / r$ & $r \mu / 0$ & TN/T & $r Y / 4$ & رواناب اندازهگيرى شده (.) & $n$ \\
\hline$r / T \Delta$ & $r / 09$ & $r / 94$ & $0 / 09$ & $r / 90$ & $r / Q V$ & $r / 91$ & $r / N I$ & $r / Q t$ & نفوذ اندازهگيرى شده (mr) & \\
\hline $1 / 1$ & I/AV & $r / 91$ & $r / 41$ & $r / 40$ & $0 / 99$ & $1 / 09$ & $1 / / V$ & $1 / \pi r$ & حجم رواناب ييشبينى شده ( & \\
\hline$r_{1 / 0}$ & $r \mathrm{r} / \mathrm{o}$ & $4 \%$ & $41 / 0$ & $41 / 0$ & $9 N / \circ$ & $r N / \circ$ & $\mu_{1 / 0}$ & $r \Delta / \circ$ & درصد رواناب يِشبينى شده (.) & $\underline{n}$ \\
\hline $1 \% / 9$ & $V / T$ & $10 / 1$ & $\varphi / 4$ & $\circ / 0$ & $1 / 19$ & $r / / V$ & $10 / 1$ & M/ & خطاى نسبى ييش بينى رواناب (.) & 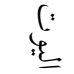 \\
\hline$r / \circ r$ & $r / q V$ & T/19 & $r / 91$ & $r / 9 V$ & $r / 9 \Lambda$ & $r / N r$ & $r / 90$ & T/AY & حجم نفوذ ييشبينى شده (mr) & \\
\hline$\Delta / r$ & $r / 1$ & IN/T & $r / \Lambda$ & $\circ / 4$ & $r \omega / \circ$ & $9 / 0$ & $r / \circ$ & $r / 9$ & خطاى نسبى بيشبينى نفوذ (٪) & \\
\hline$r /$ / & $r / l \circ$ & r/A & $r / \omega_{0}$ & $r / Q t$ & $r / 01$ & $1 / 44$ & $1 / 44$ & $1 / \pi \mathrm{o}$ & حجم رواناب يِشبينى شده (mº & \\
\hline$r 9 / 0$ & $r 4 / 0$ & $\uparrow 9 / \circ$ & $\kappa Y / 0$ & $K Y / 0$ & $Y N / \circ$ & $r 4 / 0$ & $r 9 / 0$ & $r 9 / 0$ & درصد رواناب ييشبينى شده (.) & $\underline{c}$ \\
\hline rT/T & $r \circ / 9$ & $10 / 0$ & $V / \circ$ & $1 / 9$ & $19 / \pi$ & $09 / 0$ & $T V / \Lambda$ & $11 / r$ & خطاى نسبى ييشبينى رواناب (.) & 6 \\
\hline$r / N r$ & $r / N r$ & $r / 91$ & $\varphi / \Lambda \mu$ & $4 / 19$ & $4 / \pi \Delta$ & T/AT & $r / 4$ & $r / 4 \mid$ & حجم نفوذ بيشبينى شده (mr) & $\dot{\varepsilon}$ \\
\hline$|r /|$ & $\Lambda / \Lambda$ & $I T / V$ & $\varphi / 0$ & $1 / \mu$ & $r Y / 9$ & $19 / 9$ & $10 / 9$ & $\Delta / r$ & خطاى نسبى بيشبينى نفوذ (.) & \\
\hline $1 / 11$ & I/AV & $r / 91$ & $r / 4)$ & $r / 40$ & $0 / 99$ & $1 / 09$ & $1 / 1 \mathrm{~V}$ & $1 / \pi r$ & حجم رواناب بيشبينى شده (mº & \\
\hline YN/。 & $r$ r $/ 0$ & $\Delta 9 / 0$ & $r N / \circ$ & $k T / 0$ & $\Delta Q / \circ$ & $r \%$ & $r$ r $/ 0$ & $41 / 0$ & درصد رواناب ييشبينى شده (٪) & \\
\hline $1 \pi / 9$ & $V / r$ & $10 / 1$ & $\varphi / 4$ & $\circ / 0$ & $1 N / 9$ & YI/V & $10 / 1$ & $M / 1$ & خطاى نسبى ييشبينى رواناب (.) & \\
\hline$r / \circ r$ & $r / q V$ & T/19 & $r / 91$ & $r / 9 V$ & $r / 91$ & $r / N T$ & $r / 90$ & t/AY & حجم نفوذ يِيشبينى شده (m) & 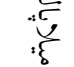 \\
\hline$\Delta / r$ & $\mu / 1$ & $I N / Y$ & $r / \Lambda$ & $0 / 4$ & $r \Delta / \circ$ & $9 / 0$ & $\psi / 0$ & $r / q$ & خطاى نسبى بيشبينى نفوذ (\%) & \\
\hline
\end{tabular}




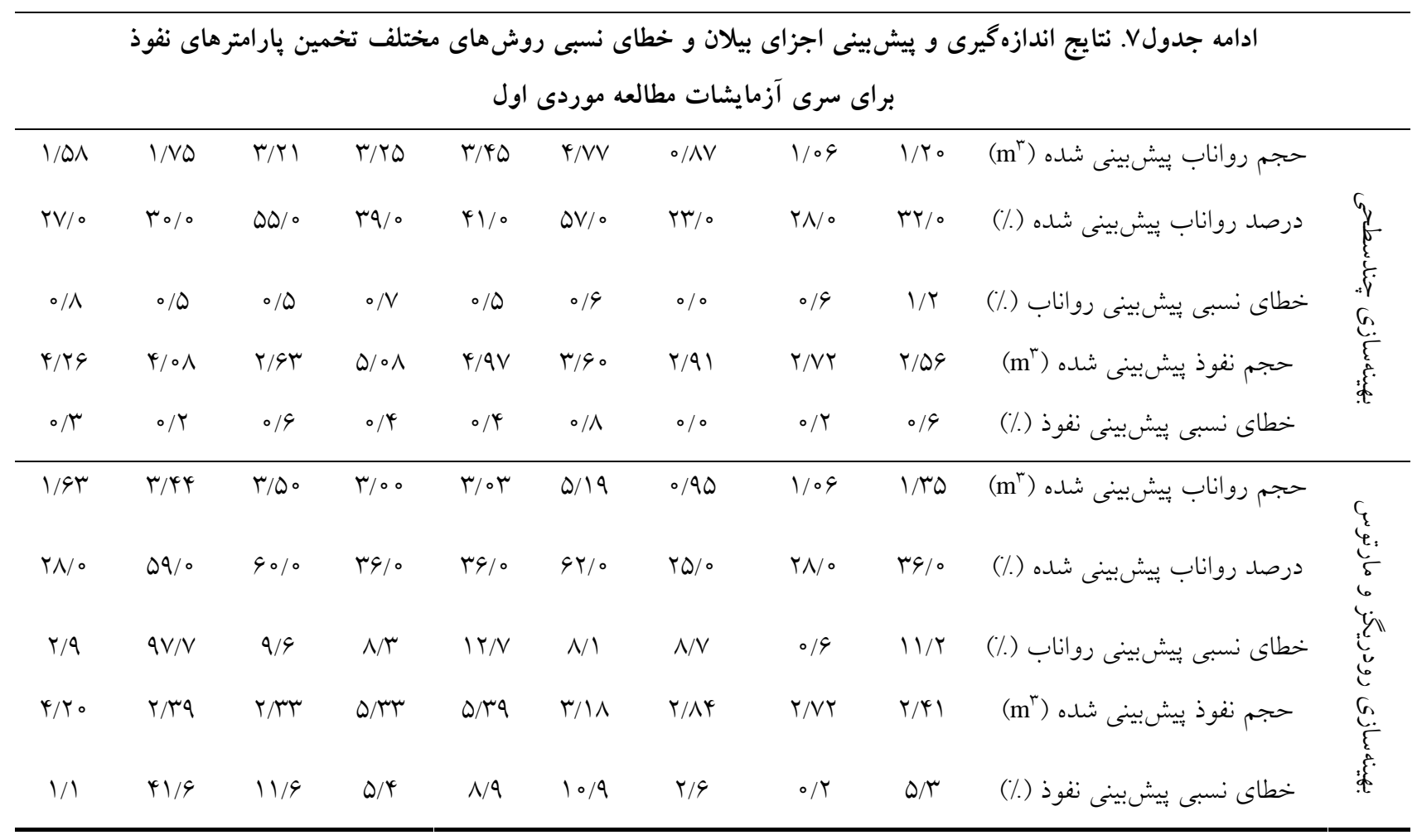

(درصورت انتها بـاز بــودن جويجتهـه) و حجــم آب نفـوذ يافتـه، اجزاى بــيلان آب را تشـكيل مسىدهنـد. نتـايج انــازه كيـرى و ييش بينى حجم رواناب، حجـم جريـان ورودى و حجـم نفـوذ، توسـط روشهـاى مختلـف تخمـين پيارامترهـاى نفـوذ مطالعـه مــوردى اول، در جــدول (V) آورده شــده اسـت. متوسـط RE بيشبينى رواناب براى يـنج روش دو نقطـهاى اليـوت و واكـر، و اليـانتزاس و همكــار ان، ميلإيـالى و همكــاران، بهينـهســازى جندسطحى و بهينه سازى رودريكز و مارتوس بـهترتيـب ل1/1/،

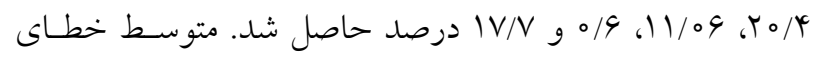

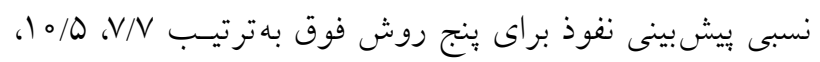

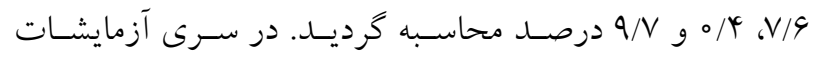

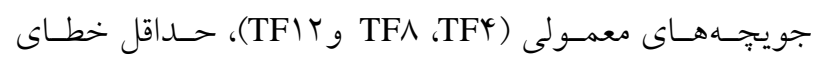
تخمين رواناب مربوط بهروش بهينهسازى جندسطحى بهدسـت

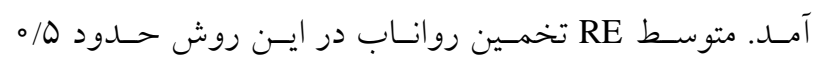
درصد حاصل شد. در جويجهاه هاى يك در مسيان ثابت (FFY) و وFF متوسط RE اين روش در سرى آزمايشات جويجهههـاى يـك در
براى جويجهه هاى معمولى، يك در مسيان ثابت و يـك در مــيان متغير، عملكرد روش بهينهسازى جندسـطحى دقيـقتـر بـوده و متوسط RMSE براى اين سـه نـوع سيسـتم آبيـارى جويتهـهاى

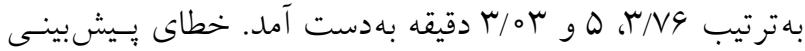
روش بهينهسازى جندسطحى در جويجهة هاى يك در ميان ثابـت نسبت به جويجه هاى معمولى و يك در ميان متغير قابل ملاحظه مىباشد. در سرى آزمايشات با كاهش دبى (آزمايشـات ا تـا م)

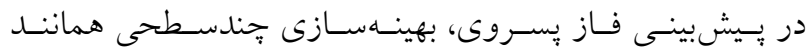
يميشبينى بيشروى، روش دقيق بـود. براسـاس نتسايج جــدول 9، متوسط RMSE بيش بينى بسروى اين روش در سرى آزمايشات با كاهش جريان برابر س/ T/ دقيقه و براى بـدون كـاهش جريـان

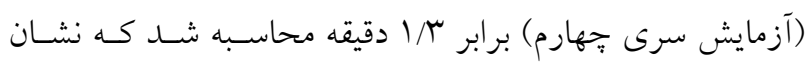

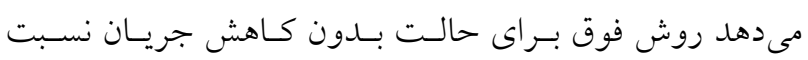
بهحالت كاهش جريان، در بيشبينى بِسروى دقيقتر است. رواناب و نفوذ در آبيارى سطحى، حجم جريان ورودى، حجم رواناب خروجى رؤى 
بهينه سازى رودريخز و مارتوس در مطالعه موردى دوم، بهترتيب

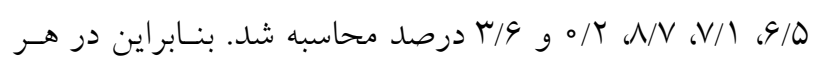

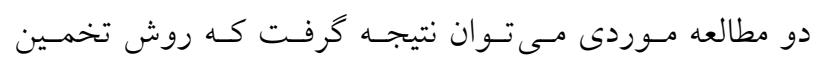

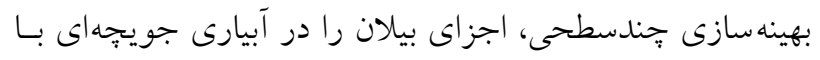

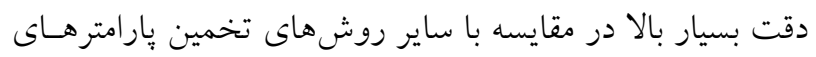

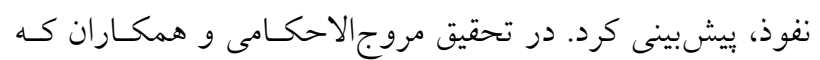
دو روش بهينهسازى جندسطحى واكـر و دو نقطهاى اليـوت و

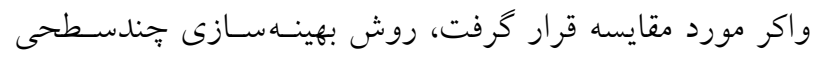

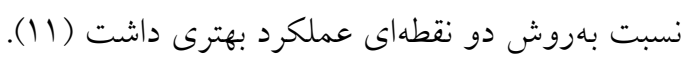

\section{نتيجه كيرى}

در اين مطالعه بهمنظـور تخمسين بارامترهـاى نفـوذ دو دسـته از

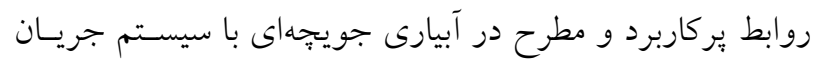

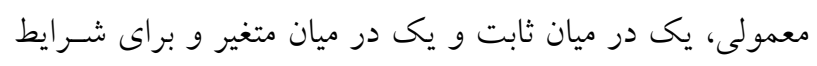

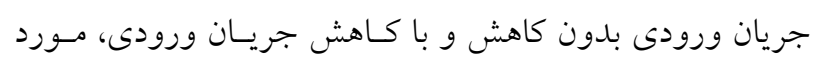

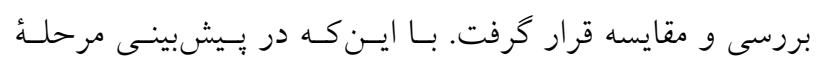

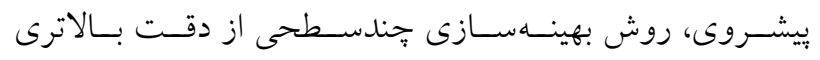

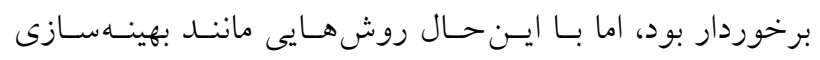

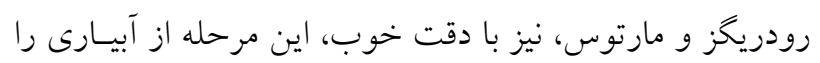

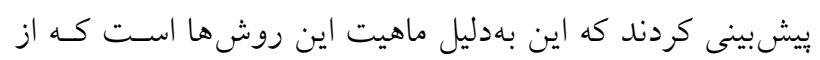

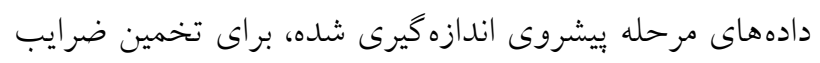

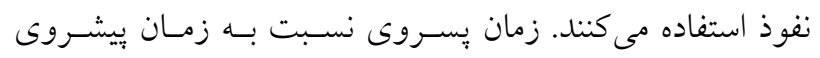

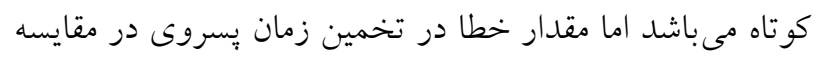

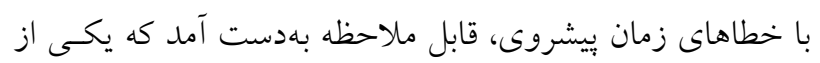

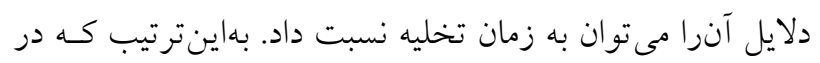

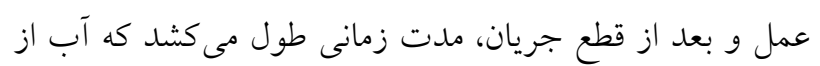
ابتداى جويجهه محو شود. اما در مدلهاى آبيارى سطحى معمولاً

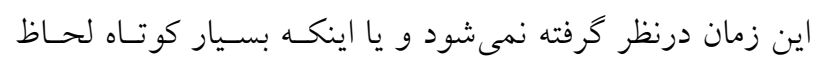

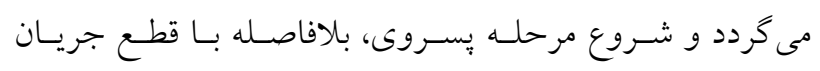

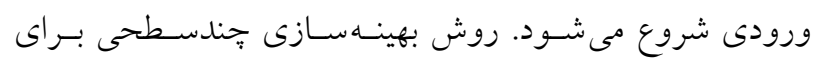

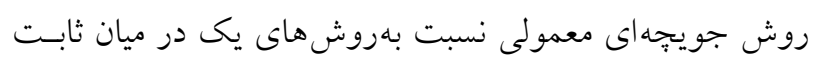

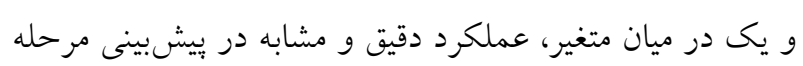

مسيان ثابت א/ه درصد محاسبه كرديد. براى جويجههاى يك در

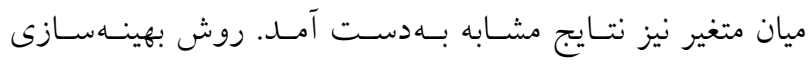
جندسطحى در جويجههاى يك در ميان متغير، دقيقتسرين روش

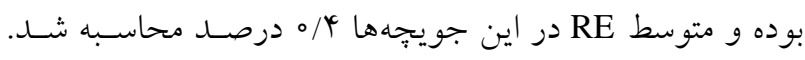

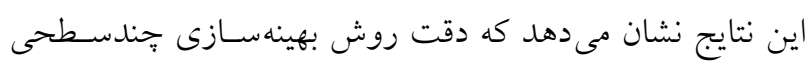

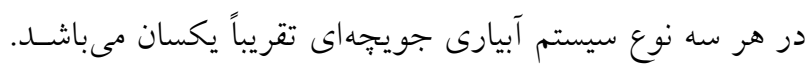
در روش بهينه سازى جند سطحى حداكثر خطاى نسبى تخمسين

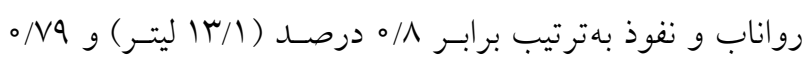

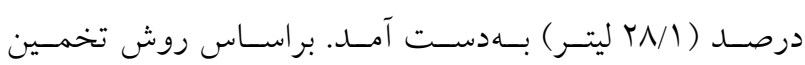
بهينه سازى جند سطحى، خطاى تخمين رواناب و نقـوذ در بـين

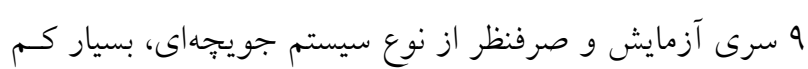

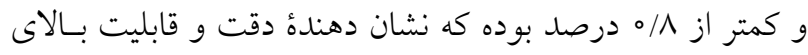

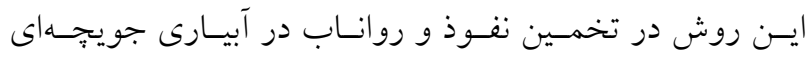
مىباشد. نتايج اندازهيرى و وييشبينى حجم رواناب، حجـم جريـان

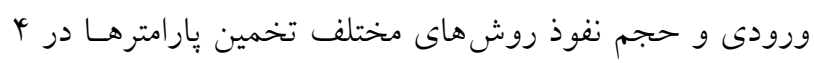

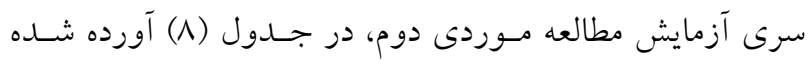

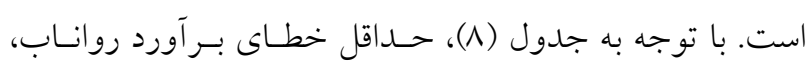

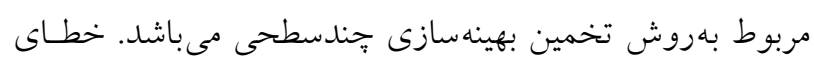

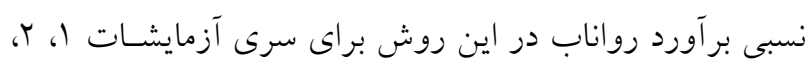

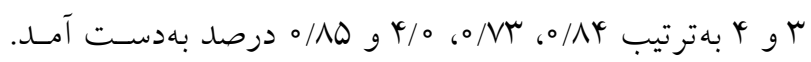

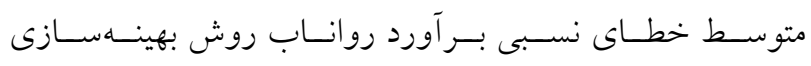

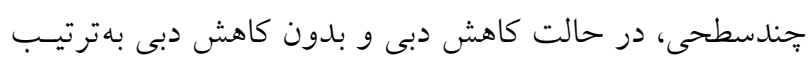

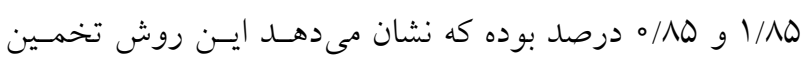

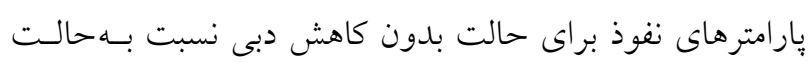

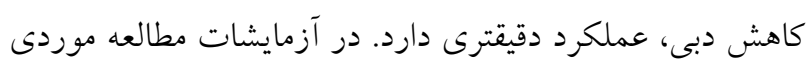

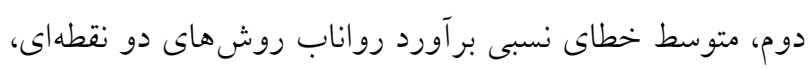

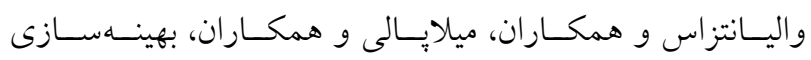

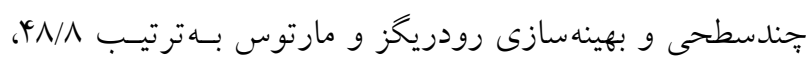

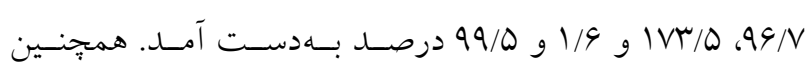

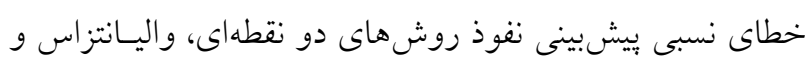

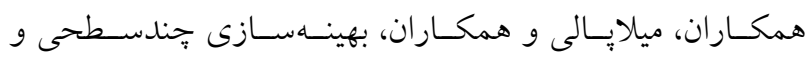


جدوله. نتايج اندازگيرى و ييشينى اجزاى بيلان و خطاى نسبى روشهاى مختلف تخمين پارامترهاى نفوذ براى سرى آزمايشات مطالعه موردى دوم

\begin{tabular}{|c|c|c|c|c|c|c|}
\hline \multirow[b]{2}{*}{ | ( } & \multicolumn{3}{|c|}{ 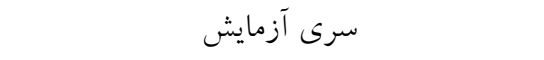 } & \multirow{2}{*}{ يَار امتر ارزيابى } & \multirow{2}{*}{\multicolumn{2}{|c|}{$\frac{\tilde{\sigma}}{\iota^{\prime}}, \underline{\xi}$}} \\
\hline & سرى ب & سرى ب | & سرى ا & & & \\
\hline $9 / 4 \wedge$ & $V / \Gamma \circ$ & $9 / 49$ & $0 / Y)$ & جريان ورودى (mr) & & 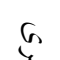 \\
\hline.$/ 19$ & $\circ / 4 \circ$ & $\circ / 99$ & $1 / 00$ & رواناب اندازهگيرى شده (mº & & $\underset{c}{2}$ \\
\hline$Y / \circ$ & $\Delta / \Delta$ & $10 / 1$ & $r q / \Lambda$ & درصد رواناب (.) & & $a$ \\
\hline $9 / 79$ & $9 / 9 \circ$ & $\Delta / \kappa_{0}$ & $r / 94$ & نفوذ اندازهيرى شده (mr) & & $\frac{\circ}{\circ}$ \\
\hline$O / Y Y$ & $\circ / \Lambda \Lambda$ & $\circ / \Lambda$ & $r / T Y$ & حجم رواناب يِشبينى شده (mr) & & $\underline{u}$ \\
\hline$T / \Delta$ & $1 \% / 0$ & $1 \% / 0$ & $41 / 0$ & درصد رواناب بيشبينى شده (\%) & & 6 \\
\hline$r G / 1$ & $11 V / 4$ & $14 / 0$ & $\mathrm{rV} / \mathrm{A}$ & خطاى نسبى بيشبينى رواناب (\%) & & 纪 \\
\hline $9 / Y^{4}$ & $G / M T$ & Q/Dr & $r / \circ V$ & حجم نفوذ ييشبينى شده (mr) & & $\frac{n}{k}$ \\
\hline$\circ / 0$ & $9 / 9$ & $r / Q$ & $19 / 0$ & خطاى نسبى بيشبينى نقوذ (\%) & & $i$ \\
\hline $0 / 99$ & $\circ / 10$ & $\circ / \mathrm{QV}$ & $1 / 09$ & حجم رواناب بيشبينى شده (mr) & & \\
\hline$V / \circ$ & $r / \circ$ & $9 / 0$ & $r y / 0$ & درصد رواناب يِيشبينى شده (.٪) & & $\bar{r}$ \\
\hline ror $/$ o & $9 \pi / \Lambda$ & $\varphi \circ / 4$ & $r q / 4$ & خطاى نسبى بيشبينى رواناب (.) & & 6 \\
\hline N/AT & $V / 10$ & $\Delta / \vee q$ & 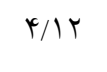 & حجم نفوذ ييشبينى شده (mr) & & $\dot{\varepsilon}$ \\
\hline $0 / 1$ & $\mathrm{r} / \mathrm{V}$ & $V / T$ & $1 Y / 0$ & خطاى نسبى بيشبينى نفوذ (\%) & & 6 \\
\hline $1 / 14$ & $\circ / \Lambda \circ$ & $1 / N T$ & $1 / V T$ & حجم رواناب بيشبينى شده (mr) & & \\
\hline $1 Y / 0$ & $11 \%$ & $T V / \circ$ & Tr/。 & درصد رواناب بيشبينى شده (\%) & & $\frac{c}{\pi}$ \\
\hline$\Delta \circ \Delta / 1$ & $99 / \%$ & $\vee \wedge / \vee$ & $10 / 9$ & خطاى نسبى بيشبينى رواناب (.) & & 6 \\
\hline$\Lambda / \mu Y$ & $9 / 0 \circ$ & $4 / 94$ & $r / 4 q$ & حجم نفوذ بيشبينى شده (m) & & $\frac{5}{5}$ \\
\hline $10 / \pi$ & $\Delta / \Lambda$ & $14 / 0$ & $4 / 9$ & خطاى نسبى بيشبينى نقوذ (\%) & & \\
\hline.$/ 19$ & $\circ / \Lambda \Lambda$ & $\circ / 90$ & $1 / 0 Y$ & حجم رواناب يِشبينى شده (mr) & & \\
\hline$r / \circ$ & $\Delta / \Gamma$ & $10 / 0$ & $r 9 / 0$ & درصد رواناب بيشبينى شده (٪) & & \\
\hline$\circ / \wedge \Delta$ & $\varphi / 0 。$ & $\circ / N r$ & $\circ / \Lambda F$ & خطاى نسبى بيشبينى رواناب (.) & & $\therefore$ \\
\hline $9 / 7 q$ & $9 / 91$ & $0 / 4+$ & $r / 9 \mathrm{~V}$ & حجم نفوذ بيشبينى شده (m) & & 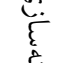 \\
\hline$\%$ & $0 / r \mu$ &.$/ 1$ & $0 / 4 G$ & خطاى نسبى بيشبينى نفوذ (\%) & & 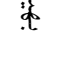 \\
\hline$\circ / \wedge \Delta$ & $0 / \pi q$ & $1 / 04$ & I/VY & حجم رواناب ييشبينى شده (mr) & & 6 \\
\hline $9 / 0$ & $4 / 0$ & $19 / 0$ & r/。 & درصد رواناب بيشبينى شده (\%) & & in \\
\hline 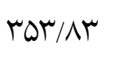 & TV/DY & $0 / \wedge 9$ & $10 / 94$ & خطاى نسبى بيشبينى رواناب (.) & $\underline{\xi}$. & $\begin{array}{l}6 \\
a\end{array}$ \\
\hline$N / g r$ & $V / 01$ & $\Delta / \mu Y$ & $r / 4 q$ & حجم نفوذ بيشبينى شده (m) & & $\xi$ \\
\hline$V / 19$ & $1 / 91$ & $1 / \circ 0$ & r/gr & خطاى نسبى بيشبينى نفوذ (٪) & & 6 \\
\hline
\end{tabular}


1/100 و ه/10 درصد محاسبه شد كه نشان مي دهد بـراى حالـت

بدون كاهش دبى نسبت بهحالت كاهش دبسى، عملكـرد دقيقتـر دارد. بهايسنترتيـب مسى تـوان نتيجهـه كرفـت كـه بــراى تخمـين يارامترهاى نفوذ، درصورتى كه از دادههاى تمام مراحـل آبيـارى

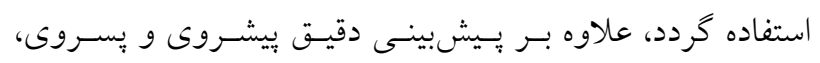

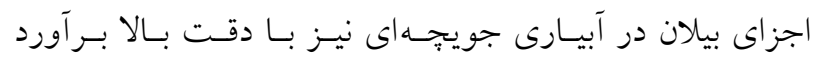
مى گردد. روش هاى تخمين دو نقطهاى، واليانتزاس و همكـاران،

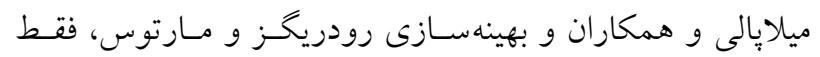
مبتنى بر دادههاى مرحله بيشروى بوده و با اينكه بيشروى را بـا

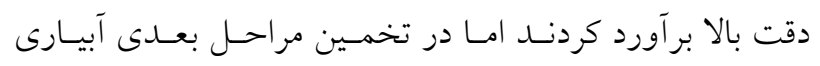

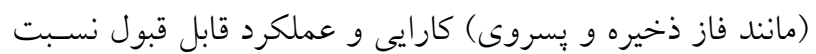
به بهينهسازى جندسطحى، نشان ندادند.
بيشروى و يُروى داشـت. در آزمايشـات بـا كـاهش دبسى نيـز بهينه سازى جندسـطحى روش دقيـق در يـيشبينسى بيشـروى و يسروى بود. در بيش بينى اجزاى بـيلان آب، روش بهينسهسازى جندسطحى نسبت به ساير روشها، با دقت بسيار بـالا روانـاب

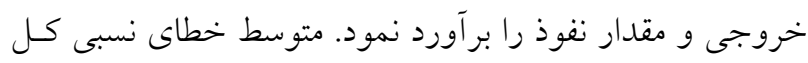
آزمايشات در تخمين رواناب، در روش بهينهازى جندسطحى،

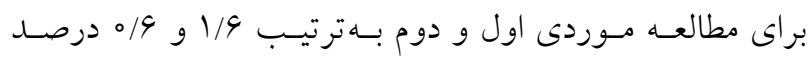

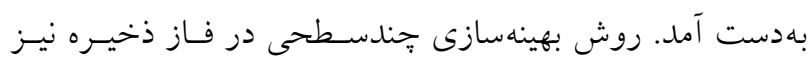
عملكرد دقيقترى نشان داد. متوسط خطاى نسـبى (RE) تخمسين رواناب در آزمايشات جويجهاى معمولى، يك در مسيان ثابـت و

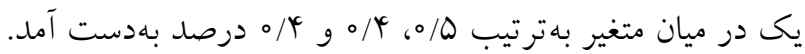
متوســط خطـاى نسـبى بـــرآورد روانـاب روش بهينـهســازى جندسطحى، در شرايط كاهش دبى و بدون كاهش دبى بهترتيب

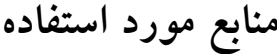

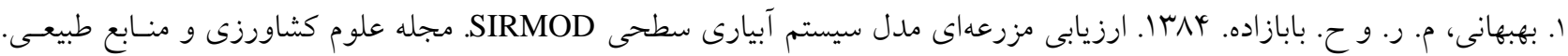
$.1-10: 1 Y(r)$

$$
\text { ז. عباسى، ف. اqهץ|. اصول جريان در آبيارى سطحى. انتشارات كميته ملى آبيارى و زهكشى ايران. }
$$

3. Bautista, E., A. J. Clemmens, T. S. Strelkoff and J. Schlegel. 2009a. Modern analysis of surface irrigation systems with WinSRFR. Agric. Water Manage. 96: 1146-1154.

4. Bautista, E., A. J. Clemmens, T. S. Strelkoff and M. Niblack. 2009b. Analysis of surface irrigation systems with WinSRFR-Example application. Agric. Water Manage. 96: 1162-1169.

5. Bautista, E., T. Strelkoff, A. J. Clemmens and D. Zerihun. 2008. Surface volume estimates for infiltration parameter estimation. In: Babcok, R .W., Walton, R. (Eds.), Proc. World environmental and water resources congress 2008, ASCE/EWRI. Hon-olulu HI, May 12-16 CDROM, 10 pp.

6. Ebrahimian, H., A. M. Liaghat, B. Ghanbarian and F. Abbasi. 2010. Evaluation of various quick methods for estimating furrow and border infiltration parameters. Irrig. Sci. 28: 479-488.

7. Elliott, R. L. and W. R. Walker. 1982. Field evaluation of furrow infiltration and advance functions. Trans. ASAE. 25 (2): 396-400.

8. Esfandiari, M. and B. L. Maheshwari. 2001. Field evaluation of surface irrigation models. J. Agric. Eng. Res. 459479.

9. McClymont, D. J. and R. J. Smith. 1996. Infiltration parameters from optimization on furrow irrigation advance data. Irrig. Sci. 17(1): 15-22.

10. Mailapalli, D. R., W. W. Wallender, N. S. Raghuwanshi and R. Singh. 2008. Quick method for estimating furrow infiltration. J. Irrig. Drain. Eng. 134(6): 788-795.

11. Moravejalahkami, B., B. Mostafazadeh-Fard, M. Heidarpour and F. Abbasi. 2009. Furrow infiltration and roughness prediction for different furrow inflow hydrographs using a zero-inertia model with a multilevel calibration approach. Biosyst. Eng. 103 (3): 371-381.

12. Renault, D. and W. W. Wallender.1997. Surface storage in furrow irrigation evaluation. J. Irrig. Drain. Eng. 123(6): 415-422.

13. Rodriguez, J. A. and J. C. Martos. 2008. SIPAR_ID: Freeware for surface irrigation parameter identification. Environ. Model. Softw. 25(11): 1487-1488.

14. Shepard J. S., W. W. Wallender and J. W. Hopmans. 1993. One method for estimating furrow infiltration. Trans. 
ASAE. 36(2): 395-404.

15. Valiantzas J. D., S. Aggelides and A. Sassalou. 2001. Furrow infiltration estimation from time to a single advance point. Agric. Water Manage. 52: 17-32.

16. Walker, W. R. 2005. Multilevel calibration of furrow infiltration and roughness. J. Irrig. Drain. Eng.. 131(2): 129136. 


\title{
Evaluation and Comparison of Different Approaches of Infiltration Parameters Estimation under Different Furrow Irrigation Systems and Inflow Regimes
}

\author{
V. Rezaverdinejad ${ }^{1 *}$, H. Ahmadi ${ }^{1}$, M. Hemmati ${ }^{1}$ and H. Ebrahimian ${ }^{2}$
}

(Received: Nov. 18-2015; Accepted: March 15-2016)

\begin{abstract}
In this study, two different approaches of infiltration parameters estimation in traditional, variable and fixed alternate furrow irrigation, with and without cutback inflow, were performed and compared. Four usual methods including twopoint (Elliott and Walker), Valiantzas one-point, Mailapalli one-point and Rodriguez and Martos optimization methods, as approaches based on advance data, and multilevel optimization method as an approach based on the advance, storage and recession data, were considered. Surface irrigation model: WinSRFR was used to simulate irrigation phases and infiltration value in each method. 13 furrow irrigation field experiments, from two case studies: Karaj and Urmia, were used to perform different methods. Based on the results, the multilevel optimization method predicted the advance and recession phases and runoff-infiltration with high accuracy for traditional, variable and fixed alternate furrow irrigation. The multilevel optimization method for traditional furrow irrigation, showed more accuracy than variable and fixed alternate furrow irrigation in advance and recession phases and the average root mean square error (RMSE) for predicting advance phase for the three furrow irrigation methods was $1.37,1.8$, and 1.57 minutes and for the recession phase was 3.76, 5.0, and 3.03 minutes, respectively. Also the multilevel optimization method for cutback options indicated high performance to advance and recession prediction and the average RMSE of advance and recession prediction were obtained 3.57 and 2.13 minutes for cutback option and 3.8 and 1.3 minutes for no cutback option, respectively. The multilevel optimization method indicated high performance in storage phase, too. The average of relative error (RE) of runoff estimation for traditional, variable and fixed alternate furrow irrigation was calculated 0.5 , 0.4 and 0.4 percent, respectively. The runoff average RE of multilevel optimization method with cutback and no cutback option were obtained 1.85 and 0.85 percent, respectively; that showed high performance of this method for no cutback option in comparison with the cutback option. Therefore, the use of data of all irrigation phases to estimate infiltration parameters shows better performance in the prediction of irrigation and water balance components. (run-off and infiltration).
\end{abstract}

Keywords: Advance, Recession, Run-off, Infiltration Function, Volume Balance Model, WinSRFR Model

1. Dept. of Water Eng., Faculty of Agric., Urmia Univ., Urmia, Iran.

2. Dept. of Irrigation and Reclamation Eng., Faculty of Agric. and Natural Resour., Tehran Univ., Tehran, Iran.

*: Corresponding author: Email: v.verdinejad@urmia.ac.ir 